\title{
A review of fundamental drivers governing the emissions, dispersion and exposure to vehicle-emitted nanoparticles at signalised traffic intersections
}

\author{
Anju Goel ${ }^{\mathrm{a}}$ and Prashant Kumar ${ }^{\mathrm{a}, \mathrm{b}, \text { * }}$
}

${ }^{a}$ Department of Civil and Environmental Engineering, Faculty of Engineering and Physical Sciences (FEPS), University of Surrey, Guildford GU2 7XH, United Kingdom

${ }^{b}$ Environmental Flow (EnFlo) Research Centre, FEPS, University of Surrey, Guildford GU2 7XH, United Kingdom

\section{Graphical abstract}

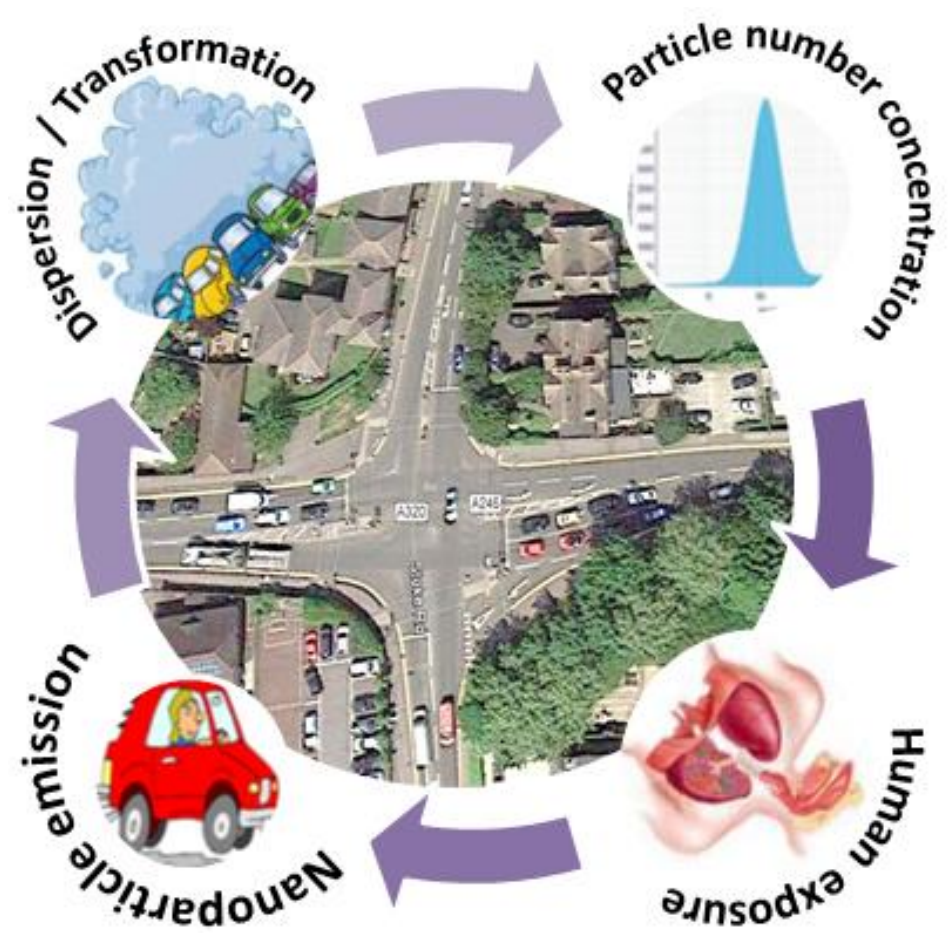

*Corresponding author: Department of Civil and Environmental Engineering, Faculty of Engineering and Physical Sciences, University of Surrey, Guildford GU2 7XH, United Kingdom; Tel.: +44 1483 682762; Fax: +44 1483 682135. E-mail addresses: P.Kumar@surrey.ac.uk,Prashant.Kumar@cantab.net

Citation details:

Goel, A., Kumar, P., 2014. A review of fundamental drivers governing the emissions, dispersion and exposure to vehicle-emitted nanoparticles at signalised traffic intersections. Atmospheric Environment 97, 316-331. Online link: http://www.sciencedirect.com/science/article/pii/S1352231014006311 


\begin{abstract}
Signalised traffic intersections (TIs) are considered as pollution hot-spots in urban areas, but the knowledge of fundamental drivers governing emission, dispersion and exposure to vehicleemitted nanoparticles (represented by particle number concentration, PNC) at TIs is yet to be established. A number of following key factors, which are important for developing an emission and exposure framework for nanoparticles at TIs, are critically evaluated as a part of this review article. In particular, (i) how do traffic- and wind-flow features affect emission and dispersion of nanoparticles? (ii) What levels of PNCs can be typically expected under diverse signal- and traffic-conditions? (iii) How does the traffic driving condition affect the particle number (PN) emissions and the particle number emission factors (PNEF)? (iv) What is the relative importance of particle transformation processes in affecting the PNCs? (v) What are important considerations for the dispersion modelling of nanoparticles? (vi) What is extent of exposure at TIs with respect to other locations in urban settings? (vii) What are the gaps in current knowledge on this topic where the future research should focus? We found that the accurate consideration of dynamic traffic flow features at TIs is essential for reliable estimates of $\mathrm{PN}$ emissions. Wind flow features at TIs are generally complex to generalise. Only a few field studies have monitored PNCs at TIs until now, reporting over an order of magnitude larger peak PNCs $\left(0.7-5.4 \times 10^{5} \mathrm{~cm}^{-3}\right)$ compared with average PNCs at typical roadsides $\left(\sim 0.3 \times 10^{5}\right.$ $\mathrm{cm}^{-3}$ ). The PN emission and thus the PNEFs can be up to an order of magnitude higher during acceleration compared with steady speed conditions. The time scale analysis suggests nucleation as the fastest transformation process, followed by dilution, deposition, coagulation and condensation. Consideration of appropriate flow features, PNEFs and transformation processes emerged as important parameters for reliable modelling of PNCs at TIs. Computation of respiratory deposition doses (RDD) based on the available PNC data suggest that the peak RDD at TIs can be up to 12-times higher compared with average RDD at urban roadsides. Systematic field and modelling studies are needed to develop a sound understanding of the emissions, dispersion and exposure of nanoparticles at the TIs.
\end{abstract}

Keywords: Airborne nanoparticles; Number size distribution; Traffic intersections; Particle dynamic; Exposure assessment

Citation details:

Goel, A., Kumar, P., 2014. A review of fundamental drivers governing the emissions, dispersion and exposure to vehicle-emitted nanoparticles at signalised traffic intersections. Atmospheric Environment 97 , 316-331. Online link: http://www.sciencedirect.com/science/article/pii/S1352231014006311 


\section{Introduction}

Airborne nanoparticles (referred here to those below $300 \mathrm{~nm}$ to represent majority of particle number concentrations, PNCs) come from a variety of exhaust and non-exhaust sources in the urban environments (Kumar et al., 2013a). Road vehicles are a major source of nanoparticle emissions (Johansson et al., 2007; Keogh et al., 2009; Kumar et al., 2011a; Shi et al., 2001), and these can contribute up to $90 \%$ of total PNC in polluted urban environments (Kumar et al., 2010a; Pérez et al., 2010; Pey et al., 2009). Small size of nanoparticles enables them to enter deeper into lungs, causing both acute and chronic adverse health effects such as asthma, cardiovascular and ischemic heart diseases (HEI, 2013). However, the number of excess deaths that occur in cities worldwide due to the exposure to nanoparticles are yet largely unknown (Kumar et al., 2014). A very few preliminary estimates are available on this topic, showing high numbers. For instance, Kumar et al. (2011b) showed that the exposure to particle number (PN) emissions from road vehicles in Delhi caused 11,252 excess deaths in 2010 that were predicted to reach to 58,268 by 2030 under the business as usual scenario.

Majority of cities worldwide are facing challenges associated with the air pollution (Kumar et al., 2013b). For example, a recent report of World Health Organisation on ambient air pollution suggests that annual mean concentration of $\mathrm{PM}_{10}$ (particulate matter less than 10 $\mu \mathrm{m})$ has increased by more than 5\% between 2008 and 2013 in 720 cities across the world (WHO, 2014). The issue of air pollution becomes more prominent at certain locations, such as signalised traffic intersections (TIs) with high pollutant concentrations, which are generally termed as "hot-spots". Whilst some studies (Mohan et al., 2007; Wu et al., 2010; Zhu et al., 2008) define hot-spots as a localised place where maxima of air pollutant concentration can occur, the United Stated Environmental Protection Agency (USEPA) defines these as small geographical locations such as the TIs and the busy roadsides where pollutant concentration is higher than the National Ambient Air Quality Standards (NAAQS). In case of airborne nanoparticles, neither such a definition nor ambient air quality standards are yet available for comparison and distinguishing the hot-spots in a particular area. Nonetheless, the same terminology can be adopted for nanoparticles by using the typical average values of PNCs in urban environments as a reference value to identify the nanoparticle hot-spots. Recently, Kumar et al. (2014) compiled the data on Citation details:

Goel, A., Kumar, P., 2014. A review of fundamental drivers governing the emissions, dispersion and exposure to vehicle-emitted nanoparticles at signalised traffic intersections. Atmospheric Environment 97 , 316-331. Online link: http://www.sciencedirect.com/science/article/pii/S1352231014006311 
roadside PNCs in 42 different cities worldwide. They found the average values of PNCs as $3.2 \pm 1.6 \times 10^{4} \mathrm{~cm}^{-3}$ and $1.2 \pm 1.0 \times 10^{5} \mathrm{~cm}^{-3}$ in European and Asian cities, respectively. These or other localised PNCs measured elsewhere can be taken as a preliminary threshold value for determining the nanoparticle hot-spots in urban areas.

Evidences of hot-spots for gaseous pollutants are available in abundance. For instance, Coelho et al. (2005) and Li et al. (2009) found that a frequent stop-and-go situation at TIs often results in excessive delays, speed variations, alleviated fuel consumption and gaseous emissions at the TIs. Likewise, hot-spots of nanoparticles can frequently occur at TIs due to the creation of pollution pockets by changing traffic conditions (e.g. accelerationdeceleration, stop-go). However, a very few studies have measured PNCs at the TIs to present an exhaustive picture of nanoparticle hot-spots in urban areas (see Table 1). These studies have found up to $\sim 17-$ and 5-folds larger values of peak PNCs at the TIs (e.g. $5.4 \pm 1.7 \times 10^{5} \mathrm{~cm}^{-3}$; Tsang et al. 2008) compared with the average typical values of roadside PNCs in European and Asian cities, respectively (Kumar et al., 2014). A number of practical and technical constraints such as portable instruments having high sampling response and broad size range, their low-cost and robustness for continuous unattended monitoring, and lack of standardised measurement methods make the study of nanoparticles at TIs even rarer (Kumar et al., 2011a). This is reflected by the fact that there are not many field studies available for TIs (Table 1), clearly indicating a need for more measurement studies to understand PNC levels in diverse traffic and driving conditions. These studies would be instrumental for developing particle number emission factors (PNEF) that are one of the key inputs for dispersion modelling which is, in turn, important for understanding the exposure to vehicle-emitted nanoparticles at TIs.

As seen in Table 2, a number of review articles are currently available in the published literature. Although these articles either deal with the flow and dispersion of gaseous pollutants at TIs (e.g. Ahmad et al., 2005; Tiwary et al., 2011) or particle transformation processes (dilution, nucleation, coagulation, condensation, evaporation and deposition) at various spatial scales (e.g. Kumar et al., 2011c; Carpentieri et al., 2011). For instance, Ahmad et al. (2005) summarised the results of wind tunnel simulations for TIs. They also discussed the effects of building configurations, canyon geometries and variability in

Goel, A., Kumar, P., 2014. A review of fundamental drivers governing the emissions, dispersion and exposure to vehicle-emitted nanoparticles at signalised traffic intersections. Atmospheric Environment 97 , 316-331. Online link: http://www.sciencedirect.com/science/article/pii/S1352231014006311 
approaching wind directions on flow fields and exhaust dispersion at TIs. Tiwary et al. (2011) reviewed the state-of-the-art knowledge on modelling the airflow and concentration fields of inert pollutants at TIs. Kumar et al. (2011c) discussed dispersion modelling techniques of nanoparticles at five local scales (vehicle wake, street, neighbourhood, city and road tunnels). However, the complexities associated with the emissions, dispersion and exposure related to vehicle-emitted PN emissions at TIs have not been discussed in detail until now (see Table 2).

The aim of this review is therefore to assess the fundamental drivers that govern the emissions, dispersion, concentration and exposure to PNCs at TIs. In order to set the background context for our review article, the key traffic and wind flow features at TIs are first briefly presented (Section 2). This is followed by an up to date summary of field studies that have monitored PNCs at TIs over the past one decade (Section 3) and the effect of traffic driving conditions and meteorology on PNEFs (Section 4). Further section presents a discussion on relative importance of particle transformation processes in altering the ambient PNCs at TIs (Section 5). A simplified approach to carry out dispersion modelling of nanoparticles at TIs is then presented (Section 6). Further, critical synthesis of published information on intermittent exposure experienced by urban dwellers at these hot-spots compared with exposures in other urban environments is discussed (Section 7). The review finally concludes with summary, conclusions and grey areas requiring further research (Section 8).

\section{Traffic and wind flow features at TIs}

Detailed study of both the traffic and wind flows at TIs is important to understand the PN emissions, dispersion and transformation of nanoparticles. Motorised road-traffic is the main source of both the PN emissions and traffic produced turbulence (TPT) at TIs. On the other hand, wind flow plays an important role in dispersion of nanoparticles released by the traffic at TIs. Since there are already specialised reviews and research articles available on this topic, as summarised in Table 2, we have briefly discussed the key traffic and wind flow features in subsequent sections for the sake of completeness and setting up context for the dispersion modelling of nanoparticles (Section 6).

\subsection{Key feature of traffic flow}

Goel, A., Kumar, P., 2014. A review of fundamental drivers governing the emissions, dispersion and exposure to vehicle-emitted nanoparticles at signalised traffic intersections. Atmospheric Environment 97, 316-331. Online link: http://www.sciencedirect.com/science/article/pii/S1352231014006311 
The estimation of PN emissions from road traffic at TIs requires in-depth understanding of traffic characteristics such as category-wise volume of traffic, technology distribution, and driving conditions (André and Hammarström, 2000). Traffic emission estimates, which are based on traffic-counts and use of different statistical methods, are often not accurate and do not reflect the dynamic behaviour of the traffic flow (Pandian et al., 2009). In-depth analysis of 'speed' and 'acceleration' in specific situations (e.g. stopand-go at traffic lights and overcrowded roads) using the traffic-flow models can provide reliable emission estimates (Pandian et al., 2009; Schmidt and Schäfer, 1998). Underestimation of vehicle speed or flow rate may lead to drastic increase in emissions (Negrenti, 1999). For instance, Eisele et al. (1996) reported that 10-30\% of underestimation of traffic volume can result in up to $50 \%$ of underestimation of carbon monoxide emissions on local arterial roads. Such an underestimation can also be expected for nanoparticle emissions. Estimates of traffic flow features based on both the traffic count and traffic-flow models are therefore necessary for accurate assessment of PN emissions at TIs (Pandian et al., 2009).

Traffic flow models can be broadly classified into three categories - microscopic, macroscopic and mesoscopic - based on their functionality. For instance, microscopic models describe both the space-time behaviour (i.e. car following, lane changing, merging, and diverging) of vehicles in short time steps (down to $0.1 \mathrm{sec}$ ). These models are used for small geographical areas such as the TIs in urban areas. Macroscopic flow models describe traffic flow at a high level of aggregation without distinguishing its constituent parts. The traffic stream is represented in an aggregate manner using characteristics such as their flowrate, density, and velocity (Tolujew and Savrasov, 2008). These models are generally used for regional or city scale transport planning and management. Mesoscopic models falls between microscopic and macroscopic models. These models simulate individual vehicles, but describe their activities and interactions based on aggregate (macroscopic) relationships. These models are used for simulating traffic characteristics on large highway networks.

Mesoscopic and macroscopic models are used to assess the larger geographical area such as large highway network and city. They cannot capture the detailed effect of traffic control at the TIs (Zhang and Ma, 2012). Therefore, microscopic simulation models are often

\section{Citation details:}

Goel, A., Kumar, P., 2014. A review of fundamental drivers governing the emissions, dispersion and exposure to vehicle-emitted nanoparticles at signalised traffic intersections. Atmospheric Environment 97 , 316-331. Online link: http://www.sciencedirect.com/science/article/pii/S1352231014006311 
preferred for TIs since these can capture dynamic movement of vehicles in detail. In-depth review of the capabilities and usefulness of these models for traffic flow modelling can be seen elsewhere (Chowdhury et al., 2000; Pandian et al., 2009).

\subsection{Key feature of wind flow}

Wind flow within and above the TIs is challenging to describe. This is because of the complex geometry, TPT, roadway design and atmospheric stability (Carpentieri et al., 2012; Tiwary et al., 2011). Wind flow at TIs is typically studied through wind tunnel experiments, numerical simulation or combination of both. A systematic review of key wind tunnel and numerical simulation studies at TIs is presented in Table 3. The findings of these studies suggest that two different types of turbulences (atmospheric and mechanical) affect the wind flows at TIs. Atmospheric turbulence is produced by: (i) the interaction of wind with the complex geometry of TIs, and (ii) the turbulence generated by the atmospheric stability conditions. Mechanical turbulence is produced due the interaction of ambient air with the moving traffic that is generally referred to as TPT. Detailed description of the effect of these turbulent mechanisms on wind flow at TIs and their relevance to nanoparticle modelling is presented in subsequent sections.

\subsubsection{Effect of wind produced turbulence (WPT) on wind flows}

When aerodynamically rough and inhomogeneous surface interacts with wind flows, turbulence is created due to the formation of an intense shear layer near the top of the canopy and by the wakes behind individual roughness elements such as towers and buildings. This turbulence is generally termed as WPT. This efficiently mixes and diffuses momentum, heat, moisture or any other scalar quantity (Roth, 2000). Detailed assessment of interaction between wind flow and surrounding geometry is therefore important in order to quantify the WPT.

The wind flow features at TIs are more complex than the flow features in a single street or road, due to the interaction of flow around several buildings and streets (Carpentieri et al., 2012). Hoydysh and Dabberdt (1994) carried out wind tunnel experiments for a grid of orthogonal streets, measuring concentrations of a tracer gas at a symmetrical TI. This study demonstrated that concentrations vary significantly at various locations around the TIs, with

\section{Citation details:}

Goel, A., Kumar, P., 2014. A review of fundamental drivers governing the emissions, dispersion and exposure to vehicle-emitted nanoparticles at signalised traffic intersections. Atmospheric Environment 97 , 316-331. Online link: http://www.sciencedirect.com/science/article/pii/S1352231014006311 
maximum values of tracer gas concentration being consistently seen at street corners. Their work also showed that the street aspect ratio had an important influence on dispersion conditions at these TIs.

Small asymmetries in geometry or wind directions can lead to a very different flow and dispersion pattern at the TIs (Balogun et al., 2010; Kastner-Klein et al., 1997; Robins et al., 2002). Scaperdas and Colvile (1999) performed Computational Fluid Dynamics (CFD) simulations to study the detailed wind flow features at a TI of symmetrical and asymmetrical canyons. Later, Soulhac et al. (2009) carried out wind tunnel experiments to study the wind flow features at a TI of symmetrical canyons. Their findings are summarised in Table 4, which suggest that pollutant transfer from one street to another is driven by the mixing at TIs in case of symmetrical street canyon geometry. However, pollutant transfer becomes significant as soon as there are minor departures from symmetrical to asymmetrical geometry of street canyons (Aristodemou et al., 2009; Balogun et al., 2010; Robins et al., 2002). Area of influence of a TI (AII) changes radically along with the changes in wind directions. For example, in case of a symmetrical TI, at reference wind direction $(\varnothing)=0^{0}$, AII penetrates to no more than two street widths into either side of the street (Garbero et al., 2010). While in case of asymmetrical TI, at $\varnothing=0^{0}$, the AII varies from $H$ to $5 H$ into either side of the street; where $H$ is the height of tallest building around the studied TI (Scaperdas and Colvile, 1999). AII becomes more extensive in case of an oblique reference wind direction. For instance, at symmetrical TI, at $\varnothing=10^{\circ}$, AII increases beyond five street widths in one side street and falls to zero in other side street (Garbero et al., 2010). A few wind tunnel (Brixey et al., 2009; Heist et al ., 2009) and CFD simulation (Brixey et al., 2009; Heist et al., 2009; Scaperdas., 2000) studies have also assessed the influence of small and tall towers placed at the corners of street canyons on the flow and turbulence field at corners of the TIs. They found that the presence of a tower enhanced wind speed in (and ventilation from) surrounding street canyons and forced a strong lateral flow into the side streets (see Table 3).

Interaction of the wind flow characteristics among the intersecting streets at the TIs is challenging to model and is still poorly understood (Balogun et al., 2010). This is mainly because the flow field data at TIs are scarce and have just started to become available. Wind flow features at the TIs affect the dilution of traffic emissions and dilution affects the Citation details:

Goel, A., Kumar, P., 2014. A review of fundamental drivers governing the emissions, dispersion and exposure to vehicle-emitted nanoparticles at signalised traffic intersections. Atmospheric Environment 97, 316-331. Online link: http://www.sciencedirect.com/science/article/pii/S1352231014006311 
transformation processes of nanoparticles. Therefore, there is a need to carry out more wind flow modelling studies by means of physical and numerical modelling to understand the key flow features and develop nanoparticle dispersion models for TIs.

\subsubsection{Effect of TPT on wind flows}

TPT is turbulent kinetic energy generated due to the movement of road traffic (Wang and Zhang, 2009). This plays an important role in the dispersion of nanoparticles near roadways, especially during low prevailing winds. For instance, Jicha et al. (2000) carried out CFD simulation and Kastner-Klein et al. (2001) performed wind tunnel experiment to study the effect of moving traffic on wind flow features in a street canyon. They both found that one-way traffic increases ventilation of a canyon during perpendicular winds by enhancing the circulation in the canyon. Berkowicz et al. (2002) found from their CFD simulations that the TPT can affect the vertical dispersion of pollutants up to a height of $\sim 4$ $\mathrm{m}$ (of $\sim 21 \mathrm{~m}$ high canyon) in a urban canopy layer. Di Sabatino et al. (2003) proposed a theoretical framework to estimate the TPT in street canyons at low wind speed conditions. They derived the parameterisation for TPT, which was suitable for low-, intermediate- and high-traffic density in street canyons. The follow-up study by Kastner-Klein et al. (2003) modified the parameterisation derived for TPT by incorporating the combined effect of WPT and TPT. Recently, Ahmad (2013) carried out a wind tunnel experiment for investigating the effects of heterogeneous traffic on line source dispersion in close proximity of a TI surrounded by symmetric street canyons. They observed that TPT greatly influences the tracer gas concentration at various points around the studied TI due to generation of large size eddies. It is clear from available studies that the effect of TPT on line source dispersion in street canyons has been carried out in some detail, but corresponding information for TIs is yet to become available in abundance.

\subsubsection{Effect of atmospheric stability on wind flows}

Atmospheric stability is defined in terms of the tendency of a parcel of air to move upward or downward after it has been displaced vertically by a small amount. This is thus an important parameter affecting dispersion or build-up of pollutants in the atmospheric environment. Uehara et al. (2000) performed the wind tunnel experiments to study the effect of atmospheric stability on wind flows in regular urban street canyons. They found that the

Goel, A., Kumar, P., 2014. A review of fundamental drivers governing the emissions, dispersion and exposure to vehicle-emitted nanoparticles at signalised traffic intersections. Atmospheric Environment 97 , 316-331. Online link: http://www.sciencedirect.com/science/article/pii/S1352231014006311 
turbulence within the canyon became weaker under stable atmospheric conditions. The mixing in the street canyon was enhanced during unstable atmospheric conditions. Later, Kikumoto et al. (2009) performed large eddy simulation to study the effect of atmospheric stability on dispersion conditions in an urban street canyon. They found that turbulence is accelerated by the buoyancy effects in street canyons during unstable atmospheric conditions. Conversely, the flow is depressed by thermal stratification in stable atmospheric conditions, and the pollutant stagnates near the bottom of the canyon. Although the effect of atmospheric stability on flow field has been studied in detail to some extent for street canyons (Tiwary et al., 2011; Uehara et al., 2000), but no such studies are available for TIs.

\section{Field measurements of particle number and size distributions at TIs}

Only a handful of studies have monitored the PNC at TIs and findings of these studies are summarised in Table 1. The peak PNC measured by these studies have been found to vary in the $0.7-5.4 \times 10^{5} \mathrm{~cm}^{-3}$ range, showing up to $\sim$-times differences among the PNCs measured by them. The lowest peak PNC $\left(0.7 \times 10^{5} \mathrm{~cm}^{-3}\right)$ was observed at a TI site in the USA where mobile measurements were taken and sulphur content in diesel and gasoline at the time of measurements was less than 10 and $30 \mathrm{ppm}$, respectively. The highest peak PNC $\left(5.4 \times 10^{5} \mathrm{~cm}^{-3}\right)$ was observed at a TI in Hong Kong where measurements were taken 1 $m$ away from the roadside and sulphur content in diesel and gasoline at time of measurement was less than 50 ppm (EPD, 2014). Kumar et al. (2014) highlighted a number of factors that are likely to be responsible for the variability observed in peak PNCs. For instance, lower cut-off for PNC measurements varied between 5 and $9 \mathrm{~nm}$ in studies listed in Table 1 and this can account for up to $\sim 12 \%$ of total PNC (Kumar et al., 2009a). Distance of measurement location from intersection is another consideration. In case of unobstructed topographic setting, PNC can decrease up to $\sim 40 \%$ of their kerbside level within a distance of $\sim 10 \mathrm{~m}$ (Kumar et al., 2014). Some of variability in PNC can be explained by seasonal effects (e.g. temperature inversion) that have been found to significantly increase the PNC during cold months (Buonanno et al., 2013). Average PNCs have been found up to $300 \%$ higher during winters than those during rainy season for identical traffic emission conditions (Byčenkienė et al., 2014). Sulphur content of diesel and gasoline used in road transport is another important factor. Reduction in sulphur content of diesel from 50 to $10 \mathrm{ppm}$ can result up to $\sim 30 \%$ reduction in PNCs (Jones et al., 2012). In summary, nearly $\sim 400 \%$ of Citation details:

Goel, A., Kumar, P., 2014. A review of fundamental drivers governing the emissions, dispersion and exposure to vehicle-emitted nanoparticles at signalised traffic intersections. Atmospheric Environment 97 , 316-331. Online link: http://www.sciencedirect.com/science/article/pii/S1352231014006311 
variability can be expected among PNC values reported in Table 1 due to experimental setup, fuel types and seasonal conditions. The rest of the variability can be attributed to the other local factors such as traffic volume, background concentration, and interrupted traffic flow and driving conditions specific to individual sampling locations.

For a detailed understanding of particle dynamic and dispersion at TIs, the combined effect of various factors such as wind and traffic flow, driving conditions, metrology and road grade on PNCs must be assessed. Out of the reviewed studies (Table 1), Fujitani et al. (2012) measured the PNCs at a TI in an open area. Holmes et al. (2005) and Oliveira et al. (2009) examined spatial distribution of PNCs around urban TI sites. Tsang et al. (2008) analysed the effect of driving conditions on PNCs at a TI. Holder et al. (2014) carried out mobile measurements to study the effect of driving conditions on concentrations of ultrafine and black carbon at a TI. Except Wang et al. (2008), none of these studies assessed the effect of flow (wind and traffic) dynamics on PNCs at TIs since this was not the original focus of these studies. Greater numbers of field studies are clearly needed to improve our understanding of the dispersion of nanoparticles at and around the TIs.

Most of the studies listed in Table 1 have used CPC (Condensation Particle Counters) or mobility particle size spectrometers that are often referred to as SMPS (Scanning Mobility Particle Sizer) or DMPS (Differential Mobility Particle Sizer) to monitor particle number size distributions at TIs (Wiedensohler et al., 2012). Depending on the manufacturer and the model number, the scanning time of SMPS varies and can be typically in the 30-300 s range, with a detection limit of up to $10^{8} \mathrm{~cm}^{-3}$ (Kumar et al., 2010a; TSI, 2014a). Same is the case with the CPC, which have a typical response time of about $5 \mathrm{~s}$ and detection limit of $10^{7} \mathrm{~cm}^{-}$ ${ }^{3}$ (TSI, 2014b). These instruments are suitable for fixed-site measurements at TIs, however their portability may be an issue for mobile measurements within the vehicles. The challenges for mobile monitoring arise due to instruments' size and a need of clean and continuous source of power (e.g. from batteries), which itself does not produce exhaust emissions (e.g. diesel electricity generators). Some of these instruments (e.g. CPC) contain a reservoir of volatile liquid butyl alcohol, which may spill during mobile measurements and there may be loss of data until it returns to normal position (PMS, 2013). Most of currently available instruments are able to measure the maximum level of concentrations expected

Goel, A., Kumar, P., 2014. A review of fundamental drivers governing the emissions, dispersion and exposure to vehicle-emitted nanoparticles at signalised traffic intersections. Atmospheric Environment 97, 316-331. Online link: http://www.sciencedirect.com/science/article/pii/S1352231014006311 
during fixed or mobile monitoring at TIs (Kumar et al., 2010a). The instruments with fast sampling response can even capture the rapid evolution of size distributions due to competing influences of transformation processes (Kumar et al., 2011c).

A very few studies have recorded the particle number size distributions at TIs. Data extracted from these studies are summarised in Supplementary Information (SI) Figure S1, which shows particle number size distributions at: (i) a TI of a highway (Fujitani et al., 2012), (ii) a TI of an arterial road (Holder et al., 2014), (iii) a TI surrounded by two street canyons that have building height between 15 and $30 \mathrm{~m}$ (Holmen et al., 2005), and (iv) at a roadside in an urban street canyon (Kumar et al., 2008a) to show their comparison with those recorded at TIs. As expected, all the TIs show much higher magnitude of particle number size distributions compared with roadside measurements in street canyons. In general, a much higher nucleation mode particles at TI can be expected due to diverse driving behaviour (e.g. acceleration, deceleration, idling) compared with the free flow traffic conditions on non-congested roads (see Section 4.1.2).

\section{PNEFs and PN emission modelling}

\subsection{PNEFs at TIs}

PNEF presents a functional relationship between PN emissions and the activity data that generate emissions. This is one of the most important input parameters for computing nanoparticle emissions and carrying out dispersion modelling. Broadly there are three methods to derive emission factors: (i) laboratory testing based on engine and chassis dynamometer studies, and (ii) direct on-road and on-board measurements under real-world driving cycle, and (iii) using inverse modelling techniques. Brief comparison of these approaches and examples are presented in Table 5.

As summarised in Table 5, a number of factors influence the estimation of PNEFs, including meteorology, road grade, vehicle types, speed, load and driving condition, lower and upper cut-off values of particle size range measured, and sulphur content of the fuel. For instance, meteorology affects the time scale and importance of various transformation processes and hence the estimates of PNEFs that are based on the environmental concentrations using the inverse modelling approach (Kumar et al., 2011c).

Citation details:

Goel, A., Kumar, P., 2014. A review of fundamental drivers governing the emissions, dispersion and exposure to vehicle-emitted nanoparticles at signalised traffic intersections. Atmospheric Environment 97, 316-331. Online link: http://www.sciencedirect.com/science/article/pii/S1352231014006311 


\subsubsection{Effect of road grade}

Road grade, which is a percentage rise or drop in vertical distance with respect to horizontal distance, also affects the PNEF estimates due to the change in the engine power demand of a vehicle. For instance, there is a less demand of engine power during downhill movement of a vehicle as compared to uphill movement, as shown in SI Figure S2. A conventional diesel bus engine was found to emit $~ 8$-times less PNCs for downhill movement as compare to uphill movement (Holmen et al., 2005). The PNEFs are therefore expected to change in the similar fashion as do the PNCs. This effect was demonstrated by Zheng et al. (2013a) where they found up to an order of magnitude larger PNEF from a heavy duty diesel truck during uphill driving compared with downhill driving. Their study measured only solid particles using a CPC that had cut-off size range of $23 \mathrm{~nm}$ and temperature of primary dilutor and evaporation tube was 150 and $350{ }^{\circ} \mathrm{C}$, respectively. Furthermore, different levels of PN emissions are expected to be released by vehicles due to differences in engine technology and fuel use. For instance, PNEF of heavy duty vehicle was found in the range of $\sim 10^{14}-10^{15} \mathrm{veh}^{-1} \mathrm{~km}^{-1}$, which are up to an order of magnitude larger than those for gasoline-fuelled $\left(\sim 10^{12}-10^{14}\right)$ and diesel-fuelled $\left(\sim 10^{14}\right)$ cars (Kumar et al., 2011c).

\subsubsection{Effect of interrupted traffic flow}

Traffic situation at TIs remains generally complex since the traffic flow is interrupted due to the restrictions laid by traffic signals. These restrictions lead to frequent changes in driving conditions such as deceleration, idle, acceleration and cruise (Papson et al., 2012). The PN emissions released during all these conditions and hence the corresponding PNEFs can also vary accordingly, due to constantly changing fuel consumption and engine load (Chen and Yu, 2007; Lei et al., 2010).

Numerous studies have measured an increase in PNCs as a result of vehicle acceleration, confirming the increased PN emissions due to accelerating conditions. For instance, Tsang et al. (2008) carried out a study to assess the pedestrian exposure to PNCs at a busy TI in Mong Kok, Hong Kong. They observed a sharp increase in PNCs as a result of vehicle acceleration after $\sim 3$ second when the traffic signal changed from red to green. Wang et al. Citation details:

Goel, A., Kumar, P., 2014. A review of fundamental drivers governing the emissions, dispersion and exposure to vehicle-emitted nanoparticles at signalised traffic intersections. Atmospheric Environment 97 , 316-331. Online link: http://www.sciencedirect.com/science/article/pii/S1352231014006311 
(2008) found that average PNCs at TIs during red-light periods are nearly 5-times higher compared to those during green-light periods (Figure 1). A most recent study by Johnston et al. (2013) monitored nanoparticles from motor vehicles at a TI in Wilmington, Delaware, USA. They observed abrupt peaks in PNCs that varied from a few second to tens of seconds after the traffic signal changed from red to green. Jayaratne et al. (2010) found up to an order of magnitude higher PN emissions during acceleration compared with steady driving conditions for diesel and CNG buses. Sulphur content of the fuel also plays a major role in the formation of nanoparticles and consequently influences the PNEFs, as discussed in Section 3.1.

\subsubsection{PNEF databases}

A number of individual studies have measured PNEFs under laboratory and realworld conditions, as summarised in Table 5. In addition to these studies, two comprehensive databases (Computer Programme to calculate Emission from Road Transport, COPERT4; and PARTICULATE; Luhana et al., 2004) based on chassis dynamometer testing are also available for the PNEFs under different driving conditions. COPERT4 provides PNEFs for solid particles in the size range of 50-1000 nm for different types of vehicles (e.g. passenger car, buses, coaches and heavy duty vehicles) under urban, rural and highway driving conditions (Ntziachristos et al., 2000). Similarly, PARTICULATE program was launched by European Union in the year 2000. The aim of this project was to study both the nucleation as well as solid particles in the $7-1000 \mathrm{~nm}$ size range by measuring them for a variety of vehicles under a range of engine capacities, fuels and technologies (Kulmala et al., 2011). However, studies covering the dynamic and complex situation of traffic emissions to estimate the PNEFs at TIs are yet rarely available. One way of accounting the effect of driving changes on nanoparticle emissions at the TIs is the estimation of PNEFs with respect to delay events (see SI Section S1). However, frequent driving changes at the TIs make the PNEFs derived by roadway or highway studies unsuitable to TIs. Despite the availability of numerous PNEF databases (Keogh et al., 2010; Keogh et al., 2009; Kumar et al., 2011c) there is clearly a lack of PNEF databank that could explicitly be applicable to emission modelling of nanoparticles at the TIs.

\subsection{Microscopic emission model}

\section{Citation details:}

Goel, A., Kumar, P., 2014. A review of fundamental drivers governing the emissions, dispersion and exposure to vehicle-emitted nanoparticles at signalised traffic intersections. Atmospheric Environment 97 , 316-331. Online link: http://www.sciencedirect.com/science/article/pii/S1352231014006311 
An approach to model the nanoparticle emissions at the TI is the use of microscopic emission models, which can provide a precise description of vehicle emission behaviour by relating emission rates to vehicle operation during a series of short time steps. These models can broadly be classified into the following categories:

- $\quad$ Statistical models: These models adopt mathematical functions of instantaneous speed and acceleration to predict the emission rates. These estimates are of generally high quality, but lack a physical interpretation and can also over-fit the calibration data (Lei et al., 2010; Rakha et al., 2004).

- Load-based models: These models estimate the fuel consumption rate of a vehicle to derive tail pipe emissions on the basis of engine out emission and efficiency of after treatment technology (Huang, 2009; Li et al., 2009). The major disadvantage with this type of models is their complex numerical structure and need of high computational efforts.

- $\quad$ Emission map models: These models are typically matrices that contain the average emission rates for combination of speed and acceleration in the driving cycles used. These are often based on steady-state data and are highly sensitive to the driving cycle, offering modest flexibility to account for important factors such as road grade, driver characteristics, or the interaction between the driver and different roadway elements (Barth et al., 1996; Huang, 2009).

A summary of the capabilities and characteristics of microscopic emission models is presented in Table 6. At present such models are available for gaseous pollutants and coarse particulate matter (on a mass basis), but not for the nanoparticles. Nonetheless, these can be adopted for nanoparticles by incorporating suitable PNEFs that are able to reflect dynamic traffic conditions seen at the TIs.

\section{Importance of particle dynamics at the TIs}

Vehicle emissions consist of hot gases and primary particles, which are highly dynamic and reactive in nature (Kumar et al., 2011c). Just after the release of PN emissions from vehicular exhaust, physical and chemical composition of particles changes rapidly due to the effect of transformation processes (Carpentieri and Kumar, 2011; Kumar et al., $2009 \mathrm{~b}$ ). In order to assess the relative importance of various transformation processes on

Goel, A., Kumar, P., 2014. A review of fundamental drivers governing the emissions, dispersion and exposure to vehicle-emitted nanoparticles at signalised traffic intersections. Atmospheric Environment 97, 316-331. Online link: http://www.sciencedirect.com/science/article/pii/S1352231014006311 
particle number and volume concentrations, we derived their time scales for typical TIs that are presented in Table 7, using the methodology described in SI Section S2. These time scales can be taken as a relative measure of the time taken to reduce the concentration of particles at TI, if the source was turned off. Thus a short time scale indicates a strong effect of that particular process on the PNCs. The time scale analysis suggests that nucleation as the most important process at TIs, followed by dilution, deposition, coagulation and condensation. Brief description of these processes, along with a comparison of their timescales for the TIs to those for the street canyons is presented. Such information is essential since an inadequate treatment of these processes may result in inaccuracies in prediction of PNCs at the TIs (Section 7).

Nucleation leads to formation of new particles (initial size around 1.5-2 nm) through gasto-particle conversion (Kulmala et al., 2004). This happens when cooling and condensation of hot gases generated from tailpipe of vehicles are mixed with the ambient air (Kumar et al., 2011c). Timescale of nucleation process at TIs is $\sim 80 \mathrm{~s}$ for the nucleation mode particles production rate of $10^{3} \mathrm{~cm}^{3} \mathrm{~s}^{-1}$ (Table 7). This time scale is $\sim 8$ times higher than those for the nucleation in street canyons ( $10 \mathrm{~s}$; SI Section S2). Due to formation of new particles, this process increases the particle number and volume concentration at the TIs.

Dilution occurs directly after the release of emissions from the tailpipe of vehicles. It is a key process that induces the other transformation processes to act and alter the number and size distributions. Time scale of dilution process at TI is estimated $\sim 10^{2} \mathrm{~s}$ (Table 7), which is up to $\sim 3$ times higher than those for regular street canyons ( $40 \mathrm{~s}$; Kumar et al. 2008b). It may increase or decrease the number and volume concentrations at the TIs, depending on the dilution ratio, meteorological parameters and gas phase chemistry.

Dry and wet deposition can be explained as the removal of the particles either at air-surface interfaces or by precipitation, respectively (Laakso et al., 2003; Seinfeld and Pandis, 2012). Dry deposition is mainly driven by Brownian diffusion and inertial impaction (Kumar et al., 2011c). Wet deposition is mainly driven by nucleation scavenging (i.e. rainout) and aerosolhydrometeor coagulation (i.e. washout). Dry deposition is one of the dominant removal mechanisms for the nucleation mode particles (Hinds, 1982). On the other hand, wet deposition (rainout) plays an important role in removing the larger-sized particles (Jacobson Citation details.

Goel, A., Kumar, P., 2014. A review of fundamental drivers governing the emissions, dispersion and exposure to vehicle-emitted nanoparticles at signalised traffic intersections. Atmospheric Environment 97, 316-331. Online link: http://www.sciencedirect.com/science/article/pii/S1352231014006311 
and Seinfeld, 2004). Timescale of dry deposition at TIs is estimated $\sim 10^{3} \mathrm{~s}$ (Table 7), which is over an order of magnitude larger than those for regular street canyons ( $~ 30 \mathrm{~s}$ and $130 \mathrm{~s}$ for 10-30 nm and 30-300 nm size of particles, respectively; Kumar et al. 2008b). Deposition process can reduce both the number and volume concentrations of particles to significant levels at the TIs.

Coagulation is a process in which particles collide due to their random (Brownian) motion and coalesce to form larger-sized particles (Kumar et al., 2011c). Time scale of polydisperse coagulation at TIs is estimated $\sim 5 \times 10^{3}$ s (Table 7), which is up to two orders of magnitude lower than those for regular street canyon $\left(\sim 5 \times 10^{5} \mathrm{~s}\right.$ for $30-300 \mathrm{~nm}$ size particles; Kumar et al. 2008b). Coagulation process reduces the number concentration of smaller particles but shows no effect on volume concentration.

Condensation and evaporation are diffusion-limited mass transfer process between the gasphase and the particle-phase, governed by the higher vapour pressure of condensable species in the air surrounding the particles (Kumar et al., 2011c). Time scale of condensation process at TIs is estimated as $\sim 0.4-8 \times 10^{4} \mathrm{~s}$ for growth rate of 1 and $20 \mathrm{~nm} \mathrm{~h}^{-1}$, respectively (Table 7), which is similar for $1 \mathrm{~nm} \mathrm{~h}^{-1}\left(\sim 10^{4} \mathrm{~s}\right)$ but about an order of magnitude lower for $20 \mathrm{~nm} \mathrm{~h}^{-1}\left(\sim 10^{5} \mathrm{~s}\right)$ than those for regular street canyons (Kumar et al., 2008b). Condensation helps to grow the volume of particles but does not change their number concentrations. Evaporation works as an opposite process to condensation where the volume of the particles reduces and in some cases it may cause the volatile particles to completely disappear (Kumar et al., 2011c).

These transformation processes are responsible for some of spatial and temporal variability in particle number and size distribution (Birmili et al., 2013). Relative contribution of various transformation processes in altering the PNCs at the TIs is not yet been experimentally quantified, but these are important to consider for more accurate dispersion modelling of PNCs at the TIs (see Section 7).

\section{Dispersion modelling techniques}

\subsection{Important considerations for dispersion modelling of nanoparticles at TIs}

\section{Citation details:}

Goel, A., Kumar, P., 2014. A review of fundamental drivers governing the emissions, dispersion and exposure to vehicle-emitted nanoparticles at signalised traffic intersections. Atmospheric Environment 97 , 316-331. Online link: http://www.sciencedirect.com/science/article/pii/S1352231014006311 
Traffic generated PN emissions often increase in the vicinity of TIs. Numerous factors such as complex wind flow patterns and transformation processes determine the concentrations of nanoparticles in the intersecting streets at TIs. A simplified approach to perform dispersion modelling of nanoparticles and associated exposure at the TIs is presented in Figure 2. Summary of a number of governing factors that can be used to assess the suitability of currently available dispersion models at TIs is presented below.

(i) Disrupted stop-and-go traffic flows at TIs compel the vehicles to accelerate and decelerate, and thereby increasing the PN emissions. Therefore the PNEFs capable of capturing the effect of these dynamic conditions at TIs are required in order to make reliable PN emissions estimates in dispersion models (Section 4.1).

(ii) TIs are regions with a significant exchange of pollutants between the intersecting streets. Therefore the dispersion models for nanoparticles should be able to take account of the complex flow field induced by these exchanges at TIs (Section 2.2).

(iii) Dispersion models should be able to adequately treat dilution and complex transformation processes that occur after the release of exhaust gases into the ambient environment (Section 5).

Consideration of (i) is related to uncertainties associated with input parameters whilst the latter two considerations (ii+iii) relate to structural uncertainties in the dispersion models (see Section 6.2).

\subsection{Suitability of currently available aerosol and inert pollutant models for TIs}

There are currently a very few models that are especially designed to predict PNCs by taking into account the particle dynamics. The summary of these models, which can be used at various spatial scales, is provided in Kumar et al. (2011c). Table 8 includes the detailed characteristics of some of these models that take into account the detailed particle dynamics at local scales and can be used at the TIs after appropriate modifications.

There are infrequent studies which have performed PNC modelling at the TIs. One such study is by Wang et al. (2013) that used CTAG (Comprehensive Turbulent Aerosol Dynamics and Gas Chemistry) model and divided the study area in two domains: "exhaustto-road" and "road-to-ambient". This model taken in to account the effect of WPT, TPT and atmospheric stability on wind flow features. To incorporate the effect of TPT at a TI, the

\section{Citation details:}

Goel, A., Kumar, P., 2014. A review of fundamental drivers governing the emissions, dispersion and exposure to vehicle-emitted nanoparticles at signalised traffic intersections. Atmospheric Environment 97 , 316-331. Online link: http://www.sciencedirect.com/science/article/pii/S1352231014006311 
study considered vehicles as stationary objects and resultant wind velocity as vector sum of external wind speed and vehicle velocity. However, interaction of the wakes of individual vehicles and external air depends upon the traffic density and surrounding geometry (Di Sabatino et al., 2003). This simplification may not truly represent the actual turbulence features at TIs. Also, this study has used the PNEF derived on the basis of average vehicle velocity and percentage of HDVs at intersecting highways. As evident from discussions presented in Section 4.1, PNEFs at TIs are highly dependent on driving conditions and consideration of average velocity is likely to affect accuracies of PN emission estimations. However, CFD models can provide detailed flow and dispersion characteristics, these are generally complex to use, require extensive computation and expertise, and are not easily accessible for free use.

A few models addressing dispersion of gaseous pollutants and particulate matter (on a mass basis) at TIs are currently available. These include Gaussian puff and hybrid models (Tiwary et al., 2011). The USEPA has recommended several Gaussian type operational air quality models such as California Line Source Model (CALINE-4), California Line Source Model with Queuing and Hotspot Calculation (CAL3QHC/CAL3QHCR), Hybrid Roadway Intersection Model (HYROAD) and Canyon Plume Box Model (CPB-3) suitable for modelling air quality near TIs (EPA, 2008). However, majority of these models do not take into account the full effect of TI's geometry and TPT on pollutant dispersion (Tiwary et al., 2011; Vardoulakis et al., 2007). This inadequate treatment of flow features may result in large uncertainties in predicted pollutant concentration at TIs. Theoretically, models for gaseous pollutants based on CFD or hybrid modelling could be modified by incorporating particle dynamics module in them and providing appropriate PNEFs for the dispersion modelling of nanoparticles at the TIs. Likewise, models developed for inert pollutant dispersion, especially for TIs (e.g. SIRANE; Soulhac et al., 2009), can be modified by incorporating dynamic PNEFs and particle dynamics modules in order to incorporate the (i+iii) consideration (Section 6.1).

One of the major limitations is that the currently available dispersion models are developed for inert pollutants, based on the simplified geometries of TIs, and therefore may not be applicable elsewhere. At the same time, it is not feasible to develop a single "universal"

Citation details:

Goel, A., Kumar, P., 2014. A review of fundamental drivers governing the emissions, dispersion and exposure to vehicle-emitted nanoparticles at signalised traffic intersections. Atmospheric Environment 97 , 316-331. Online link: http://www.sciencedirect.com/science/article/pii/S1352231014006311 
model that can be used for all different types of geometric configurations of TIs. Development of geometry-specific dispersion models, which can also account for particle transformation, are therefore needed for reliable estimation of PNCs and exposure at the TIs.

\section{Exposure assessment at TIs}

Understanding of spatio-temporal distribution of nanoparticles in urban environments is of significant concern for the accurate exposure assessment (Birmili et al., 2013; Kumar et al., 2014). To compare the PNC exposure observed in different urban environments, an extensive review of existing studies, falling into 4 different categories (urban background, street canyon, roadside and traffic intersections), is carried out. Details of these studies and summary of their results are presented in SI Table S1 and Figure 3, respectively. Average PNC and geometrical mean diameter of particle size distributions for each environment was calculated by averaging studies in individual categories. Figure $3 \mathrm{a}$ clearly shows that the highest average PNCs are observed at TIs, followed by the roadside, street canyons, and urban background. Average PNCs at TIs were found to be $\sim 1.5$ and 1.9times higher than those in roadside and street canyons, respectively. It is worth noting that these comparisons are based on the averaged PNCs and if short term averaging (e.g. $1 \mathrm{~s}$ ) during peak conditions is considered the corresponding differences were found to increase to $\sim 17$ and 21-times, respectively. The higher PNCs at TIs are expected due to complex wind flow conditions (Section 3.2) accompanied by frequent changes in driving conditions of vehicles (Section 5.1). An interesting trend emerged from this analysis, showing an exponential increase in PNCs from urban background, to street canyons, to roadside, to PNCs at TIs with a significant correlation factor $\left(R^{2}=0.98\right.$; Figure 3a). An interpretation of this relationship could be that if PNC of any of the above-mentioned environments is known, the PNC in other environments can be approximated by using the exponential relationship seen in Figure 3a. For example, Birmili et al. (2013) measured PNCs at the urban background and roadside locations in Dresden, Germany. By using the relationship shown in Fig 3a, roadside PNCs are predicted as $2.1 \times 10^{4} \mathrm{~cm}^{-3}$ based on measured urban background PNCs $\left(9.8 \times 10^{3} \mathrm{~cm}^{-3}\right)$. These predicted values show a fractional bias of $\sim 0.29$ compared with those actually measured at the roadside $\left(2.8 \times 10^{4} \mathrm{~cm}^{-3}\right)$, indicating these within the generally expected fractional bias range of \pm 0.5 (Rim et al., 2013). However, this

Goel, A., Kumar, P., 2014. A review of fundamental drivers governing the emissions, dispersion and exposure to vehicle-emitted nanoparticles at signalised traffic intersections. Atmospheric Environment 97, 316-331. Online link: http://www.sciencedirect.com/science/article/pii/S1352231014006311 
is a statistical relationship based on a limited dataset and therefore should be generalised cautiously.

Higher PNC does not mean higher respiratory deposited doses (RDD), as the fraction of nanoparticle deposited in respiratory system depends upon the size of particles (ICRP, 1994). RDD is higher for small size particles and decreases in power form for larger particles, as demonstrated by a variety of urban PNC studies (Al-Dabbous and Kumar, 2014; Kumar and Morawska, 2014; Kumar et al., 2014). Therefore, understanding of particle size distribution is crucial for accurate estimation of RDD. In this study, RDD rate in each environment is calculated using methodology presented in Section S3. As expected, the highest RDD rate based on the average PNCs is found at the TIs $\left(\sim 3.0 \pm 1.6 \times 10^{10} \mathrm{~h}^{-1}\right)$, followed by roadside $\left(\sim 2.8 \pm 1.8 \times 10^{10} \mathrm{~h}^{-1}\right)$, street canyon $\left(\sim 1.8 \pm 0.5 \times 10^{10} \mathrm{~h}^{-1}\right)$ and urban background $\left(\sim 1.3 \pm 1.8 \times 10^{10} \mathrm{~h}^{-1}\right)$ locations (Figure $3 \mathrm{~b}$ ). It is worth noting that these estimates are based on the average PNCs observed in each environment and consideration of peak PNCs might further increase the RDD rate. For instance, total RDD rate becomes $34.2 \times 10^{10} \mathrm{~h}^{-1}$ based on peak PNC observed at TIs (see Table 1), which is $\sim 12$-times higher than those estimated on the basis of average roadside PNCs.

Short-term exposure under peak PNC conditions at TIs is not very well characterised, but this may contribute to significant portion of daily exposure of urban dwellers. For instance, a commuter will get exposed to $\sim 4.3 \times 10^{9}$ particles over the period of delay time, which is typically $\sim 46 \mathrm{~s}$ at many TIs (Zheng et al., 2013b). Assuming that an individual crosses one TI during a day, exposure to this individual at that TI may contribute as much as $13 \%$ of total exposure during a typical daily commuting time of $\sim 1.5$ hours (Fruin et al., 2008; Ragettli et al., 2013) that give a total RDD of $\sim 34.4 \times 10^{9}$ particles.

It is evident from the above discussions that some studies are conducted for TIs of regular street canyons (Table 1), but there is clearly a need for more experimental investigations in order to understand the extent of exposure at TIs under diverse geometrical configurations as well as flow and driving conditions of traffic. Such studies could also assist in developing a database, showing the contribution of exposure at TIs towards the overall daily exposure during commuting in diverse city environments.

\section{Citation details:}

Goel, A., Kumar, P., 2014. A review of fundamental drivers governing the emissions, dispersion and exposure to vehicle-emitted nanoparticles at signalised traffic intersections. Atmospheric Environment 97 , 316-331. Online link: http://www.sciencedirect.com/science/article/pii/S1352231014006311 


\section{Summary, conclusion and future directions}

The article presents a critical assessment of the important aspects of traffic and wind flow features, emissions, particle dynamics and dispersion modelling of nanoparticles at TIs. Implications of PNCs at TIs towards the exposure to traffic-emitted nanoparticles are also discussed. Numerous types of models available for traffic flow modelling at TIs are reviewed and the effects of atmospheric- and mechanical-produced turbulence on wind flow features at TIs are discussed.

Although some information is currently available on the effects of wind direction and surrounding geometry on wind flow feature at the TIs, information on the effect of TPT and atmospheric stability on wind flow feature at TIs is still limited. So far, only a few field studies have measured the PNCs at the TIs and up to date summary of these field studies is collated. PNEFs at TIs are dynamic and information on them is hardly available. Relative importance of transformation processes is assessed based on the time scale analysis. The features and limitations of currently available aerosol and inert pollutant models are presented that can be considered for dispersion modelling of nanoparticles at the TIs. A need of more field and modelling studies is recognised since these are crucial for improved understanding of particle transformation, dispersion and associated exposure at the TIs. Comparative assessment of exposure to PNCs at TIs with different urban environment is also performed, along with highlighting key areas for further research. The key conclusions drawn from this review are summarised below:

- Microscopic models are found to be suitable for traffic flow modelling at TIs since they can capture the dynamic behaviour of road vehicles in short time steps.

- Wind flow features at TIs are highly sensitive to local geometry, atmospheric stability, TPT and wind direction. Intensity of WPT varies significantly at various points at and around the TIs, and therefore the TIs cannot be considered as uniformly-mixed zones.

- $\quad$ Majority of the current studies have monitored PNCs only at one fixed location at a particular TI. Whilst such measurements provide indicative levels of PNCs, these measurements do not provide detailed insight on the effects of complex wind flow features and variable emission on particle dynamics and dispersion around the TIs. 
- The PNEFs are highly variable and depend upon meteorology, driving conditions, engine speed, engine load, fuel sulphur content, and road grade. Data available on PNEFs under real-world driving conditions, capturing the effect of frequent start-go and acceleration-deceleration experienced at TIs, is nearly non-existent.

- The time scale analysis suggested that the nucleation is the most important transformation process among others at the TIs, followed by dilution, deposition, coagulation, condensation and evaporation for the consideration in dispersion modelling.

- A very few aerosol dynamic models are suitable for dispersion modelling of nanoparticles at the TIs, but these models are complex to use and require excessive computation resources. Models available for gaseous and particulate matter can possibly be modified by incorporating appropriate PNEFs and particle dynamic modules to predict nanoparticles at TIs.

- $\quad$ RDD rate based on peak PNCs at TIs is found to be $\sim 12$-times higher than those based on the average PNCs at urban roadsides. Short-term exposure to nanoparticles at TIs may contribute a significant portion of total exposure during daily commuting. A very few studies have assessed exposure to PNCs at TIs and therefore the extent of exposure at a broad variety of TIs is yet poorly understood.

There are a number of key questions that need to be addressed through further research. For example, limited information is available on wind flow features at TIs and presently available studies have focused on physical transfer processes (mass and momentum), but how this knowledge can be extended for exposure evaluation is needed to be explored. Only a handful of studies have tried to assess the effect of driving conditions on PNEFs in real world situation, but the effect of delay event on PN emission at TIs is poorly understood. Information on relevance of various transformation processes at TIs is scarcely available. Moreover, the contribution of these transformation processes in changing the PNCs between the traffic exhaust and receptor locations at TIs is still poorly studied. Currently available models for dispersion modelling at TIs are developed for simplified geometries that cannot be generalised. Adequate characterisation of complex geometry requires consideration of numerous factors such as size and shape of intersections, details of roofs, and building 
walls. Combination of all these complexities suggests a need to understand the science behind the nanoparticle dispersion at the TIs. There is also a need of more field studies in order to map the PNC around TIs and understand the particle dynamics and their dispersion. Such studies will be of great relevance in evaluation of PNC dispersion models and accurate assessment of exposure at the TIs.

\section{Acknowledgements}

Authors greatly acknowledge the financial support received from the UK Commonwealth Commission through the Commonwealth Scholarship to AG for her PhD research. They also thank the Department of Civil \& Environmental Engineering at the University of Surrey (UK) for partially supporting the project activities.

\section{References}

Ahmad, K., 2013. Physical simulation of automobile exhausts dispersion at an urban intersection - Part II: Traffic induced effects. International Journal of Engineering Research and Applications 3, 887-890.

Ahmad, K., Khare, M., Chaudhry, K.K., 2005. Wind tunnel simulation studies on dispersion at urban street canyons and intersections - a review. Journal of Wind Engineering and Industrial Aerodynamics 93, 697-717.

Al-Dabbous, A.N., Kumar, P., 2014. The influence of roadside vegetation barriers on airborne nanoparticles and pedestrians exposure under varying wind conditions. Atmospheric Environment 90, 113-124.

André, M., Hammarström, U., 2000. Driving speeds in Europe for pollutant emissions estimation. Transportation Research Part D: Transport and Environment 5, 321-335.

Aristodemou, E., Bentham, T., Pain, C., Colvile, R., Robins, A., ApSimon, H., 2009. A comparison of mesh-adaptive LES with wind tunnel data for flow past buildings: Mean flows and velocity fluctuations. Atmospheric Environment 43, 6238-6253.

Axer, S., Rohde, J., Friedrich, B., 2012. Level of service estimation at traffic signals based on innovative traffic data services and collection techniques. Procedia - Social and Behavioral Sciences 54, 159-168.

Balogun, A.A., Tomlin, A.S., Wood, C.R., Barlow, J.F., Belcher, S.E., Smalley, R.J., Lingard, J.J., Arnold, S.J., Dobre, A., Robins, A.G., 2010. In-street wind direction variability in the vicinity of a busy intersection in central London. Boundary-Layer Meteorology 136, 489-513.

Barth, M., An, F., Norbeck, J., Ross, M., 1996. Modal emissions modeling: A physical approach. Transportation Research Record 1520, 81-88.

Berkowicz, R., Ketzel, M., Vachon, G., Louka, P., Rosant, J.-M., Mestayer, P., Sini, J.-F., 2002. Examination of traffic pollution distribution in a street canyon using the Nantes' 99 experimental data and comparison with model results. Water, Air and Soil Pollution: Focus 2, 311-324.

Citation details:

Goel, A., Kumar, P., 2014. A review of fundamental drivers governing the emissions, dispersion and exposure to vehicle-emitted nanoparticles at signalised traffic intersections. Atmospheric Environment 97, 316-331. Online link: http://www.sciencedirect.com/science/article/pii/S1352231014006311 
Birmili, W., Alaviippola, B., Hinneburg, D., Knoth, O., Tuch, T., Borken-Kleefeld, J., Schacht, A., 2009. Dispersion of traffic-related exhaust particles near the Berlin urban motorway - estimation of fleet emission factors. Atmospheric Chemistry and Physics 9, 2355-2374.

Birmili, W., Tomsche, L., Sonntag, A., Opelt, C., Weinhold, K., Nordmann, S., Schmidt, W., 2013. Variability of aerosol particles in the urban atmosphere of Dresden (Germany): Effects of spatial scale and particle size. Meteorologische Zeitschrift 22, 195-211.

Biswas, P., Wu, C.-Y., 2005. Nanoparticles and the environment. Journal of the Air \& Waste Management Association 55, 708-746.

Boogaard, H., Montagne, D.R., Brandenburg, A.P., Meliefste, K., Hoek, G., 2010. Comparison of short-term exposure to particle number, $\mathrm{PM}_{10}$ and soot concentrations on three (sub) urban locations. Science of the Total Environment 408, 4403-4411.

Boulter, P., McCrae, I.S., Barlow, T.J., 2007. A review of instantaneous emission models for road vehicles. TRL Limited. pp. 64. Available from: http://docs.niwa.co.nz/library/public/PPR267.pdf (accessed 04 October 2013).

Brixey, L.A., Heist, D.K., Richmond-Bryant, J., Bowker, G.E., Perry, S.G., Wiener, R.W., 2009. The effect of a tall tower on flow and dispersion through a model urban neighborhoodPart 2. Pollutant dispersion. Journal of Environmental Monitoring 11, 2171-2179.

Buonanno, G., Fuoco, F.C., Morawska, L., Stabile, L., 2013. Airborne particle concentrations at schools measured at different spatial scales. Atmospheric Environment 67, 38-45.

Buseck, P.R., Adachi, K., 2008. Nanoparticles in the atmosphere. Elements 4, 389-394.

Byčenkienė, S., Plauškaite, K., Dudoitis, V., Ulevicius, V., 2014. Urban background levels of particle number concentration and sources in Vilnius, Lithuania. Atmospheric Research 143, 279-292.

Can, A., Rademaker, M., Van Renterghem, T., Mishra, V., Van Poppel, M., Touhafi, A., Theunis, J., De Baets, B., Botteldooren, D., 2011. Correlation analysis of noise and ultrafine particle counts in a street canyon. Science of the Total Environment 409, 564-572.

Carpentieri, M., Hayden, P., Robins, A.G., 2012. Wind tunnel measurements of pollutant turbulent fluxes in urban intersections. Atmospheric Environment 46, 669-674.

Carpentieri, M., Kumar, P., 2011. Ground-fixed and on-board measurements of nanoparticles in the wake of a moving vehicle. Atmospheric Environment 45, 58375852.

Carpentieri, M., Kumar, P., Robins, A., 2011. An overview of experimental results and dispersion modelling of nanoparticles in the wake of moving vehicles. Environmental Pollution 159, 685-693.

Carpentieri, M., Robins, A.G., Baldi, S., 2009. Three-dimensional mapping of air flow at an urban canyon intersection. Boundary-Layer Meteorology 133, 277-296.

Chen, K., Yu, L., 2007. Microscopic traffic-emission simulation and case study for evaluation of traffic control strategies. Journal of Transportation Systems Engineering and Information Technology 7, 93-99.

Chen, M., Titcombe, M., Jiang, J., Jen, C., Kuang, C., Fischer, M.L., Eisele, F.L., Siepmann, J.I., Hanson, D.R., Zhao, J., McMurry, P.H., 2012. Acid-base chemical reaction

Citation details:

Goel, A., Kumar, P., 2014. A review of fundamental drivers governing the emissions, dispersion and exposure to vehicle-emitted nanoparticles at signalised traffic intersections. Atmospheric Environment 97 , 316-331. Online link: http://www.sciencedirect.com/science/article/pii/S1352231014006311 
model for nucleation rates in the polluted atmospheric boundary layer. Proceedings of the National Academy of Sciences 109, 18713-18718.

Chowdhury, D., Santen, L., Schadschneider, A., 2000. Statistical physics of vehicular traffic and some related systems. Physics Reports 329, 199.

Coelho, M.C., Farias, T.L., Rouphail, N.M., 2005. Impact of speed control traffic signals on pollutant emissions. Transportation Research Part D: Transport and Environment 10, 323-340.

Dabberdt, W., Hoydysh, W., Schorling, M., Yang, F., Holynskyj, O., 1995. Dispersion modeling at urban intersections. Science of the Total Environment 169, 93-102.

Di Sabatino, S., Kastner-Klein, P., Berkowicz, R., Britter, R.E., Fedorovich, E., 2003. The Modelling of Turbulence from Traffic in Urban Dispersion Models - Part I: Theoretical Considerations. Environmental Fluid Mechanics 3, 129-143.

Eisele, W.L., Turner, S., Benz, R.W., 1996. Using acceleration characteristics in air quality and energy consumption analyses. Southwest Region University Transportation Center, Texas Transportation Institute. 96. http://d2dt15nnlpfr0r.cloudfront.net/tti.tamu.edu/documents/465100-1.pdf (accssed 10 October 2013).

EPA, 2008. Emission and air quality modelling tools for near-roadway applications (Report No.EPA/600/R-09/011). http://nepis.epa.gov/Exe/ZyPDF.cgi/P1003MVX.PDF?Dockey=P1003MVX.PDF (accessed 10 October 2013).

EPD, 2014. Review of the air quality objectives and development of a long term air quality strategy for Hong Kong - feasibility study (Agreement No. CE57/2006). http://www.epd.gov.hk/epd/english/environmentinhk/air/studyrpts/files/executive_su mmary_en.pdf (accessed 30 March 2014).

Franco, V., Kousoulidou, M., Muntean, M., Ntziachristos, L., Hausberger, S., Dilara, P., 2013. Road vehicle emission factors development: A review. Atmospheric Environment 70, 84-97.

Fruin, S., Westerdahl, D., Sax, T., Sioutas, C., Fine, P.M., 2008. Measurements and predictors of on-road ultrafine particle concentrations and associated pollutants in Los Angeles. Atmospheric Environment 42, 207-219.

Fujitani, Y., Sakamoto, T., Misawa, K., 2012. Quantitative determination of composition of particle type by morphology of nanoparticles in diesel exhaust and roadside atmosphere. Journal of Civil \& Environmental Engineering S1:002. doi:10.4172/2165$784 X$.

Gadilhe, A., Janvier, L., Barnaud, G., 1993. Numerical and experimental modelling of the three-dimensional turbulent wind flow through an urban square. Journal of Wind Engineering and Industrial Aerodynamics 46-47, 755-763.

Garbero, V., Salizzoni, P., Soulhac, L., 2010. Experimental study of pollutant dispersion within a network of streets. Boundary-layer meteorology 136, 457-487.

Gramsch, E., Gidhagen, L., Wahlin, P., Oyola, P., Moreno, F., 2009. Predominance of sootmode ultrafine particles in Santiago de Chile: Possible sources. Atmospheric Environment 43, 2260-2267.

Hak, C.S., Hallquist, M., Ljungström, E., Svane, M., Pettersson, J.B.C., 2009. A new approach to in-situ determination of roadside particle emission factors of individual vehicles under conventional driving conditions. Atmospheric Environment 43, 24812488 .

Citation details:

Goel, A., Kumar, P., 2014. A review of fundamental drivers governing the emissions, dispersion and exposure to vehicle-emitted nanoparticles at signalised traffic intersections. Atmospheric Environment 97, 316-331. Online link: http://www.sciencedirect.com/science/article/pii/S1352231014006311 
HEI Review Panel on Ultrafine particles, 2013. Understanding the health effects of ambient ultrafine particles HEI Perspectives 3. Health Effects Institute, Boston, MA, p. 122. http://pubs.healtheffects.org/getfile.php? u=893 (accessed 30 March 2014)

Heist, D.K., Brixey, L.A., Richmond-Bryant, J., Bowker, G.E., Perry, S.G., Wiener, R.W., 2009. The effect of a tall tower on flow and dispersion through a model urban neighborhoodPart 1. Flow characteristics. Journal of Environmental Monitoring 11, 2163-2170.

Hinds, W.C., 1982. Aerosol technology: properties, behavior, and measurement of airborne particles. Wiley Interscience, $2^{\text {nd }}$ Edition. pp. 483.

Holder, A.L., Hagler, G.S.W., Yelverton, T.L.B., Hays, M.D., 2014. On-road black carbon instrument intercomparison and aerosol characteristics by driving environment. Atmospheric Environment 88, 183-191.

Holmen, B.A., Chen, Z., Davila, A.C., Gao, O., Vikara, D.M., 2005. Particulate matter emissions from hybrid diesel-electric and conventional diesel transit buses: Fuel and aftertreatment effects. Final report: http://www.cti.uconn.edu/pdfs/jhr05-304_03-8.pdf (accessed 10 December 2013).

Holmes, N.S., Morawska, L., 2006. A review of dispersion modelling and its application to the dispersion of particles: An overview of different dispersion models available. Atmospheric Environment 40, 5902-5928.

Holmes, N.S., Morawska, L., Mengersen, K., Jayaratne, E., 2005. Spatial distribution of submicrometre particles and $\mathrm{CO}$ in an urban microscale environment. Atmospheric Environment 39, 3977-3988.

Hoydysh, W.G., Dabberdt, W.F., 1994. Concentration fields at urban intersections: fluid modeling studies. Atmospheric Environment 28, 1849-1860.

Huang, Z., 2009. Dynamic emission prediction platform and it's integration with microscopic traffic simulation. Uppsala University. Report: http://uu.divaportal.org/smash/get/diva2:233900/FULLTEXT01.pdf

ICRP, 1994. Human respiratory tract model for radiological protection: A report of a task group of the International Commission on Radiological Protection. Elsevier Science Health Science Division. Annals of the ICRP 24, 1-8.

Jacobson, M.Z., Seinfeld, J.H., 2004. Evolution of nanoparticle size and mixing state near the point of emission. Atmospheric Environment 38, 1839-1850.

Janhäll, S., M Jonsson, Å., Molnár, P., A Svensson, E., Hallquist, M., 2004. Size resolved traffic emission factors of submicrometer particles. Atmospheric Environment 38, 4331-4340.

Jayaratne, E.R., Meyer, N.K., Ristovski, Z.D., Morawska, L., Miljevic, B., 2010. Critical Analysis of High Particle Number Emissions from Accelerating Compressed Natural Gas Buses. Environmental Science \& Technology 44, 3724-3731.

Jayaratne, E.R., Ristovski, Z.D., Meyer, N., Morawska, L., 2009. Particle and gaseous emissions from compressed natural gas and ultralow sulphur diesel-fuelled buses at four steady engine loads. Science of the Total Environment 407, 2845-2852.

Jicha, M., Pospisil, J., Katolicky, J., 2000. Dispersion of pollutants in street canyon under traffic induced flow and turbulence. Environmental Monitoring and Assessment 65, 343-351.

Johansson, C., Norman, M., Gidhagen, L., 2007. Spatial \& temporal variations of $\mathrm{PM}_{10}$ and particle number concentrations in urban air. Environmental Monitoring and Assessment 127, 477-487.

Citation details:

Goel, A., Kumar, P., 2014. A review of fundamental drivers governing the emissions, dispersion and exposure to vehicle-emitted nanoparticles at signalised traffic intersections. Atmospheric Environment 97 , 316-331. Online link: http://www.sciencedirect.com/science/article/pii/S1352231014006311 
Johnston, M.V., Klems, J.P., Zordan, C.A., Pennington, M.R., Smith, J.N., 2013. Selective detection and characterization of nanoparticles from motor vehicles. Research report (Health Effects Institute), pp. 3-45.

Jones, A.M., Harrison, R.M., Barratt, B., Fuller, G., 2012. A large reduction in airborne particle number concentrations at the time of the introduction of "sulphur free" diesel and the London Low Emission Zone. Atmospheric Environment 50, 129-138.

Ju-Nam, Y., Lead, J.R., 2008. Manufactured nanoparticles: An overview of their chemistry, interactions and potential environmental implications. Science of the Total Environment 400, 396-414.

Kastner-Klein, P., Fedorovich, E., Ketzel, M., Berkowicz, R., Britter, R., 2003. The modelling of turbulence from traffic in urban dispersion models - Part II: Evaluation against laboratory and full-scale concentration measurements in street canyons. Environmental Fluid Mechanics 3, 145-172.

Kastner-Klein, P., Fedorovich, E., Rotach, M.W., 2001. A wind tunnel study of organised and turbulent air motions in urban street canyons. Journal of Wind Engineering and Industrial Aerodynamics 89, 849-861.

Kastner-Klein, P., Plate, E., Fedorovich, E., 1997. Gaseous pollutant dispersion around urban-canopy elements: wind tunnel case studies. International Journal of Environment and Pollution 8, 727-737.

Keogh, D., Kelly, J., Mengersen, K., Jayaratne, R., Ferreira, L., Morawska, L., 2010. Derivation of motor vehicle tailpipe particle emission factors suitable for modelling urban fleet emissions and air quality assessments. Environmental Science \& Pollution Research 17, 724-739.

Keogh, D.U., Ferreira, L., Morawska, L., 2009. Development of a particle number and particle mass vehicle emissions inventory for an urban fleet. Environmental Modelling \& Software 24, 1323-1331.

Keogh, D.U., Sonntag, D., 2011. Challenges and approaches for developing ultrafine particle emission inventories for motor vehicle and bus fleets. Atmosphere 2, 36-56.

Kerminen, V.-M., Lehtinen, K.E.J., Anttila, T., Kulmala, M., 2004. Dynamics of atmospheric nucleation mode particles: a timescale analysis. Tellus B 56, 135-146.

Ketzel, M., Berkowicz, R., 2004. Modelling the fate of ultrafine particles from exhaust pipe to rural background: an analysis of time scales for dilution, coagulation and deposition. Atmospheric Environment 38, 2639-2652.

Ketzel, M., Berkowicz, R., 2005. Multi-plume aerosol dynamics and transport model for urban scale particle pollution. Atmospheric Environment 39, 3407-3420.

Kikumoto, H., Ooka, R., Uehara, K., 2009. Large-eddy simulation of gaseous diffusion in street canyon with thermal stratification. The Seventh Asia-Pacific Conference on Wind Engineering, November 8-12, 2009, Taipei, Taiwan.

Klein, P., Leitl, B., Schatzmann, M., 2007. Driving physical mechanisms of flow and dispersion in urban canopies. International Journal of Climatology 27, 1887-1907.

Knibbs, L.D., Cole-Hunter, T., Morawska, L., 2011. A review of commuter exposure to ultrafine particles and its health effects. Atmospheric Environment 45, 2611-2622.

Kukačka, L., Nosek, Š., Kellnerová, R., Jurčáková, K., Jaňour, Z., 2012. Wind tunnel measurement of turbulent and advective scalar fluxes: a case study on intersection ventilation. The Scientific World Journal 381357, doi: 10.1100/2012/38135.

Kulmala, M., Asmi, A., Lappalainen, H., Baltensperger, U., Brenguier, J.-L., Facchini, M., Hansson, H.-C., Hov, Ø., O'Dowd, C., Pöschl, U., 2011. General overview: European

Citation details:

Goel, A., Kumar, P., 2014. A review of fundamental drivers governing the emissions, dispersion and exposure to vehicle-emitted nanoparticles at signalised traffic intersections. Atmospheric Environment 97, 316-331. Online link: http://www.sciencedirect.com/science/article/pii/S1352231014006311 
Integrated project on Aerosol Cloud Climate and Air Quality interactions (EUCAARI) - integrating aerosol research from nano to global scales. Atmospheric Chemistry and Physics 11, 13061-13143.

Kulmala, M., Vehkamäki, H., Petäjä, T., Dal Maso, M., Lauri, A., Kerminen, V.M., Birmili, W., McMurry, P.H., 2004. Formation and growth rates of ultrafine atmospheric particles: a review of observations. Journal of Aerosol Science 35, 143-176.

Kumar, P., Fennell, P., Britter, R., 2008a. Measurements of particles in the 5-1000 nm range close to road level in an urban street canyon. Science of the Total Environment 390, 437-447.

Kumar, P., Fennell, P., Langley, D., Britter, R., 2008b. Pseudo-simultaneous measurements for the vertical variation of coarse, fine and ultrafine particles in an urban street canyon. Atmospheric Environment 42, 4304-4319.

Kumar, P., Fennell, P., Hayhurst, A., Britter, R., 2009a. Street versus rooftop level concentrations of fine particles in a Cambridge street canyon. Boundary-Layer Meteorology 131, 3-18.

Kumar, P., Robins, A., Britter, R., 2009b. Fast response measurements of the dispersion of nanoparticles in a vehicle wake and a street canyon. Atmospheric Environment 43, 6110-6118.

Kumar, P., Robins, A., Vardoulakis, S., Britter, R., 2010a. A review of the characteristics of nanoparticles in the urban atmosphere and the prospects for developing regulatory controls. Atmospheric Environment 44, 5035-5052.

Kumar, P., Fennell, P., Robins, A., 2010b. Comparison of the behaviour of manufactured and other airborne nanoparticles and the consequences for prioritising research and regulation activities. Journal Nanoparticle Research 12, 1523-1530.

Kumar, P., Robins, A., ApSimon, H., 2010c. Nanoparticle emissions from biofuelled vehicles - their characteristics and impact on the number-based regulation of atmospheric particles. Atmospheric Science Letters 11, 327-331.

Kumar, P., Robins, A., Vardoulakis, S., Quincey, P., 2011a. Technical challenges in tackling regulatory concerns for urban atmospheric nanoparticles. Particuology 9, 566571.

Kumar, P., Gurjar, B., Nagpure, A., Harrison, R.M., 2011b. Preliminary estimates of nanoparticle number emissions from road vehicles in megacity Delhi and associated health impacts. Environmental Science \& Technology 45, 5514-5521.

Kumar, P., Ketzel, M., Vardoulakis, S., Pirjola, L., Britter, R., 2011c. Dynamics and dispersion modelling of nanoparticles from road traffic in the urban atmospheric environment-A review. Journal of Aerosol Science 42, 580-603.

Kumar, P., Mulheron, M., Fisher, B., Harrison, R.M., 2012. New Directions: Airborne ultrafine particle dust from building activities-a source in need of quantification. Atmospheric Environment 56, 262-264.

Kumar, P., Pirjola, L., Ketzel, M., Harrison, R.M., 2013a. Nanoparticle emissions from 11 non-vehicle exhaust sources - A review. Atmospheric Environment 67, 252-277.

Kumar, P., Jain, S., Gurjar, B.R., Sharma, P., Khare, M., Morawska, L., Britter, R., 2013b. New Directions: Can a "blue sky" return to Indian megacities? Atmospheric Environment 71, 198-201.

Kumar, P., Morawska, L., 2014. Recycling concrete: An undiscovered source of ultrafine particles. Atmospheric Environment 90, 51-58.

Citation details:

Goel, A., Kumar, P., 2014. A review of fundamental drivers governing the emissions, dispersion and exposure to vehicle-emitted nanoparticles at signalised traffic intersections. Atmospheric Environment 97, 316-331. Online link: http://www.sciencedirect.com/science/article/pii/S1352231014006311 
Kumar, P., Morawska, L., Birmili, W., Paasonen, P., Hu, M., Kulmala, M., Harrison, R.M., Norford, L., Britter, R., 2014. Ultrafine particles in cities. Environment International $66,1-10$.

Laakso, L., Grönholm, T., Rannik, Ü., Kosmale, M., Fiedler, V., Vehkamäki, H., Kulmala, M., 2003. Ultrafine particle scavenging coefficients calculated from 6 years field measurements. Atmospheric Environment 37, 3605-3613.

Rim, D., Persily, A., Emmerich, S., Dols, W.S., Wallace, L., 2013. Multi-zone modeling of size-resolved outdoor ultrafine particle entry into a test house. Atmospheric Environment 69, 219-230.

Lei, W., Chen, H., Lu, L., 2010. Microscopic emission and fuel consumption modeling for light-duty vehicles using portable emission measurement system data. World Academy of Science, Engineering and Technology 42, 918-925.

Li, M., Boriboonsomsin, K., Wu, G., Zhang, W.-B., Barth, M., 2009. Traffic energy and emission reductions at signalized intersections: a study of the benefits of advanced driver information. International Journal of ITS Research 7, 49-58.

Li, X., Li, G., Pang, S.-S., Yang, X., Tian, J., 2004. Signal timing of intersections using integrated optimization of traffic quality, emissions and fuel consumption: a note. Transportation Research Part D: Transport and Environment 9, 401-407.

Lingard, J.J.N., Agus, E.L., Young, D.T., Andrews, G.E., Tomlin, A.S., 2006. Observations of urban airborne particle number concentrations during rush-hour conditions: analysis of the number based size distributions and modal parameters. Journal of Environmental Monitoring 8, 1203-1218.

Luhana, L., Sokhi, R., Warner, L., Mao, H., Boulter, P., McCrae, I.S., 2004. Measurement of non-exhaust particulate matter. Characterisation of exhaust particulate emissions from road vehicles (PARTICULATES). Deliverable 8 of the European Commission DG TrEn 5th Framework PARTICULATES project.

Mohan, M., Dagar, L., Gurjar, B.R., 2007. Preparation and validation of gridded emission inventory of criteria air pollutants and identification of emission hotspots for megacity Delhi. Environmental Monitoring and Assessment 130, 323-339.

Morawska, L., 2010. Airborne engineered nanoparticles: are they a health problem? Air Quality and Climate Change 44, 18.

Morawska, L., Bofinger, N.D., Kocis, L., Nwankwoala, A., 1998. Submicrometer and supermicrometer particles from diesel vehicle emissions. Environmental Science \& Technology 32, 2033-2042.

Morawska, L., Jamriska, M., Thomas, S., Ferreira, L., Mengersen, K., Wraith, D., McGregor, F., 2005. Quantification of particle number emission factors for motor vehicles from on-road measurements. Environmental Science \& Technology 39, 91309139.

Morawska, L., Jayaratne, E.R., Knibbs, L.D., Megatmokhtar, M., 2011. Regulations and policy measures related to the reduction of ambient particulate matter, In: Zereini, F., Wiseman, C.L.S. (Eds.), Urban Airborne Particulate Matter. Environmental Science and Engineering, pp. 599-622.

Morawska, L., Ristovski, Z., Jayaratne, E., Keogh, D.U., Ling, X., 2008. Ambient nano and ultrafine particles from motor vehicle emissions: characteristics, ambient processing and implications on human exposure. Atmospheric Environment 42, 8113-8138.

Morawska, L., Thomas, S., Hofmann, W., Ristovski, Z., Jamriska, M., Rettenmoser, T., Kagerer, S., 2004. Exploratory cross-sectional investigations on ambient

Citation details:

Goel, A., Kumar, P., 2014. A review of fundamental drivers governing the emissions, dispersion and exposure to vehicle-emitted nanoparticles at signalised traffic intersections. Atmospheric Environment 97, 316-331. Online link: http://www.sciencedirect.com/science/article/pii/S1352231014006311 
submicrometer particles in Salzburg, Austria. Atmospheric Environment 38, 35293533.

Morawska, L., Wang, H., Ristovski, Z., Jayaratne, E., Johnson, G., Cheung, H.C., Ling, X., He, C., 2009. JEM spotlight: Environmental monitoring of airborne nanoparticles. Journal of Environmental Monitoring 11, 1758-1773.

Negrenti, E., 1999. The 'Corrected Average Speed'approach in ENEA's TEE model: an innovative solution for the evaluation of the energetic and environmental impacts of urban transport policies. Science of the Total Environment 235, 411-413.

Nickel, C., Kaminski, H., Hellack, B., Quass, U., John, A., Klemm, O., Kuhlbusch, T.A., 2013. Size resolved particle number emission factors of motorway traffic differentiated between heavy and light duty vehicles. Aerosol and Air Quality Research 13, 450-461.

Nowack, B., Bucheli, T.D., 2007. Occurrence, behavior and effects of nanoparticles in the environment. Environmental Pollution 150, 5-22.

Ntziachristos, L., Samaras, Z., Eggleston, S., Gorissen, N., Hassel, D., Hickman, A., 2000. COPERT III. Computer Programme to calculate emissions from road transport, methodology and emission factors (version 2.1), European Energy Agency (EEA), Copenhagen.

Oliveira, C., Alves, C., Pio, C.A., 2009. Aerosol particle size distributions at a traffic exposed site and an urban background location in Oporto, Portugal. Química Nova 32, 928-933.

Ondráček, J., Schwarz, J., Ždímal, V., Andělová, L., Vodička, P., Bízek, V., Tsai, C.J., Chen, S.C., Smolík, J., 2011. Contribution of the road traffic to air pollution in the Prague city (busy speedway and suburban crossroads). Atmospheric Environment 45, 5090-5100.

Pandian, S., Gokhale, S., Ghoshal, A.K., 2009. Evaluating effects of traffic and vehicle characteristics on vehicular emissions near traffic intersections. Transportation Research Part D: Transport and Environment 14, 180-196.

Papson, A., Hartley, S., Kuo, K.-L., 2012. Analysis of emissions at congested and uncongested intersections with motor vehicle emission simulation 2010. Transportation Research Record: Journal of the Transportation Research Board 2270, 124-131.

Pérez, N., Pey, J., Cusack, M., Reche, C., Querol, X., Alastuey, A., Viana, M., 2010. Variability of particle number, black carbon, and $\mathrm{PM}_{10}, \mathrm{PM}_{2.5}$, and $\mathrm{PM}_{1}$ levels and speciation: Influence of road traffic emissions on urban air quality. Aerosol Science and Technology 44, 487-499.

Pey, J., Querol, X., Alastuey, A., Rodríguez, S., Putaud, J.P., Van Dingenen, R., 2009. Source apportionment of urban fine and ultra-fine particle number concentration in a Western Mediterranean city. Atmospheric Environment 43, 4407-4415.

Pirjola, L., Paasonen, P., Pfeiffer, D., Hussein, T., Hämeri, K., Koskentalo, T., Virtanen, A., Rönkkö, T., Keskinen, J., Pakkanen, T.A., Hillamo, R.E., 2006. Dispersion of particles and trace gases nearby a city highway: Mobile laboratory measurements in Finland. Atmospheric Environment 40, 867-879.

PMS, 2013. Basic guide to particle counters and particle counting. Particle measuring systems, USA. http://www.pmeasuring.com/wrap/filesApp/BasicGuide/file_1/ver_1317144880/basicg uide.pdf (accessed 04 August 2014).

Citation details:

Goel, A., Kumar, P., 2014. A review of fundamental drivers governing the emissions, dispersion and exposure to vehicle-emitted nanoparticles at signalised traffic intersections. Atmospheric Environment 97, 316-331. Online link: http://www.sciencedirect.com/science/article/pii/S1352231014006311 
Putaud, J.P., Van Dingenen, R., Alastuey, A., Bauer, H., Birmili, W., Cyrys, J., Flentje, H., Fuzzi, S., Gehrig, R., Hansson, H.C., Harrison, R.M., Herrmann, H., Hitzenberger, R., Hüglin, C., Jones, A.M., Kasper-Giebl, A., Kiss, G., Kousa, A., Kuhlbusch, T.A.J., Löschau, G., Maenhaut, W., Molnar, A., Moreno, T., Pekkanen, J., Perrino, C., Pitz, M., Puxbaum, H., Querol, X., Rodriguez, S., Salma, I., Schwarz, J., Smolik, J., Schneider, J., Spindler, G., ten Brink, H., Tursic, J., Viana, M., Wiedensohler, A., Raes, F., 2010. A European aerosol phenomenology - 3: Physical and chemical characteristics of particulate matter from 60 rural, urban, and kerbside sites across Europe. Atmospheric Environment 44, 1308-1320.

Qiao, F., Yi, P., Yang, H., Devarakonda, S., 2002. Fuzzy logic based intersection delay estimation. Mathematical and Computer Modelling 36, 1425-1434.

Quiroga, C.A., Bullock, D., 1999. Measuring control delay at signalized intersections. Journal of Transportation Engineering 125, 271-280.

Ragettli, M.S., Corradi, E., Braun-Fahrländer, C., Schindler, C., de Nazelle, A., Jerrett, M., Ducret-Stich, R.E., Künzli, N., Phuleria, H.C., 2013. Commuter exposure to ultrafine particles in different urban locations, transportation modes and routes. Atmospheric Environment 77, 376-384.

Rakha, H., Ahn, K., Trani, A., 2003. Comparison of MOBILE5a, MOBILE6, VT-MICRO, and CMEM models for estimating hot-stabilized light-duty gasoline vehicle emissions. Canadian Journal of Civil Engineering 30, 1010-1021.

Rakha, H., Ahn, K., Trani, A., 2004. Development of VT-Micro model for estimating hot stabilized light duty vehicle and truck emissions. Transportation Research Part D: Transport and Environment 9, 49-74.

Reche, C., Querol, X., Alastuey, A., Viana, M., Pey, J., Moreno, T., Rodríguez, S., González, Y., Fernández-Camacho, R., de la Rosa, J., Dall'Osto, M., Prévôt, A.S.H., Hueglin, C., Harrison, R.M., Quincey, P., 2011. New considerations for PM, Black Carbon and particle number concentration for air quality monitoring across different European cities. Atmospheric Chemistry and Physics 11, 6207-6227.

Ristovski, Z., Morawska, L., Ayoko, G.A., Johnson, G., Gilbert, D., Greenaway, C., 2004. Emissions from a vehicle fitted to operate on either petrol or compressed natural gas. Science of the Total Environment 323, 179-194.

Ristovski, Z.D., Jayaratne, E.R., Morawska, L., Ayoko, G.A., Lim, M., 2005. Particle and carbon dioxide emissions from passenger vehicles operating on unleaded petrol and LPG fuel. Science of the total environment 345, 93-98.

Robins, A., Savory, E., Scaperdas, A., Grigoriadis, D., 2002. Spatial variability and sourcereceptor relations at a street intersection. Water, Air and Soil Pollution: Focus 2, 381393.

Roldin, P., Swietlicki, E., Schurgers, G., Arneth, A., Lehtinen, K.E.J., Boy, M., Kulmala, M., 2011. Development and evaluation of the aerosol dynamics and gas phase chemistry model ADCHEM. Atmospheric Chemistry and Physics 11, 5867-5896.

Rosenbohm, E., Vogt, R., Scheer, V., Nielsen, O.J., Dreiseidler, A., Baumbach, G., Imhof, D., Baltensperger, U., Fuchs, J., Jaeschke, W., 2005. Particulate size distributions and mass measured at a motorway during the BAB II campaign. Atmospheric Environment 39, 5696-5709.

Roth, M., 2000. Review of atmospheric turbulence over cities. Quarterly Journal of the Royal Meteorological Society 126, 941-990.

Citation details:

Goel, A., Kumar, P., 2014. A review of fundamental drivers governing the emissions, dispersion and exposure to vehicle-emitted nanoparticles at signalised traffic intersections. Atmospheric Environment 97, 316-331. Online link: http://www.sciencedirect.com/science/article/pii/S1352231014006311 
Samaras, Z., Ntziachristos, L., Thompson, N., Hallb, D., Westerholm, R., Boulterd, P., 2005. Characterisation of exhaust particulate emissions from road vehicles. PARTICULATES Program, European Commission Contract, 11091.

Scaperdas, A.-S., 2000. Modelling air flow and pollutant dispersion at urban canyon intersections. Imperial College London (University of London). PhD Thesis.

Scaperdas, A., Colvile, R., 1999. Assessing the representativeness of monitoring data from an urban intersection site in central London, UK. Atmospheric Environment 33, 661674.

Schmidt, M., Schäfer, R.-P., 1998. An integrated simulation system for traffic induced air pollution. Environmental Modelling \& Software 13, 295-303.

Seinfeld, J.H., Pandis, S.N., 2012. Atmospheric chemistry and physics: from air pollution to climate change. John Wiley \& Sons. pp. 1203.

Shi, J.P., Evans, D.E., Khan, A., Harrison, R.M., 2001. Sources and concentration of nanoparticles $(<10 \mathrm{~nm}$ diameter $)$ in the urban atmosphere. Atmospheric Environment 35, 1193-1202.

Simonet, B.M., Valcárcel, M., 2009. Monitoring nanoparticles in the environment. Analytical and Bioanalytical Chemistry 393, 17-21.

Soulhac, L., Garbero, V., Salizzoni, P., Mejean, P., Perkins, R., 2009. Flow and dispersion in street intersections. Atmospheric Environment 43, 2981-2996.

Tiwary, A., Robins, A., Namdeo, A., Bell, M., 2011. Air flow and concentration fields at urban road intersections for improved understanding of personal exposure. Environment International 37, 1005-1018.

Tolujew, J., Savrasov, M., 2008. Transport System Mesoscopic Model Validation Using Simulation on Microlevel, Proc. of the 8th International Conference, Reliability and Statistics in Transportation and Communication.-Riga: Transport and Telecommunication Institute, Kabashkin IV, Yatskiv IV (eds.), pp. 297-304.

Tsang, H., Kwok, R., Miguel, A.H., 2008. Pedestrian exposure to ultrafine particles in Hong Kong under heavy traffic conditions. Aerosol and Air Quality Research 8, 19-27.

TSI, 2014a. Description of scanning mobility particle sizer. http://www.tsi.com/uploadedFiles/Product_Information/Literature/Spec_Sheets/SMPS 3936-3034.pdf (accessed 04 August 2014).

TSI, 2014b. Condensation particle counter model 3775, http://www.tsi.com/uploadedFiles/_Site_Root/Products/Literature/Spec_Sheets/3775_ 2980343.pdf (accessed 04 August 014).

Uehara, K., Murakami, S., Oikawa, S., Wakamatsu, S., 2000. Wind tunnel experiments on how thermal stratification affects flow in and above urban street canyons. Atmospheric Environment 34, 1553-1562.

Väkevä, M., Hämeri, K., Kulmala, M., Lahdes, R., Ruuskanen, J., Laitinen, T., 1999. Street level versus rooftop concentrations of submicron aerosol particles and gaseous pollutants in an urban street canyon. Atmospheric Environment 33, 1385-1397.

Vardoulakis, S., Valiantis, M., Milner, J., ApSimon, H., 2007. Operational air pollution modelling in the UK-Street canyon applications and challenges. Atmospheric Environment 41, 4622-4637.

Virtanen, A., Rönkkö, T., Kannosto, J., Ristimäki, J., Mäkelä, J.M., Keskinen, J., Pakkanen, T., Hillamo, R., Pirjola, L., Hämeri, K., 2006. Winter and summer time size distributions and densities of traffic-related aerosol particles at a busy highway in Helsinki. Atmospheric Chemistry and Physics 6, 2411-2421.

Citation details:

Goel, A., Kumar, P., 2014. A review of fundamental drivers governing the emissions, dispersion and exposure to vehicle-emitted nanoparticles at signalised traffic intersections. Atmospheric Environment 97 , 316-331. Online link: http://www.sciencedirect.com/science/article/pii/S1352231014006311 
Voigtländer, J., Tuch, T., Birmili, W., Wiedensohler, A., 2006. Correlation between traffic density and particle size distribution in a street canyon and the dependence on wind direction. Atmospheric Chemistry and Physics 6, 4275-4286.

von Bismarck-Osten, C., Birmili, W., Ketzel, M., Massling, A., Petäjä, T., Weber, S., 2013. Characterization of parameters influencing the spatio-temporal variability of urban particle number size distributions in four European cities. Atmospheric Environment 77, 415-429.

Wåhlin, P., 2009. Measured reduction of kerbside ultrafine particle number concentrations in Copenhagen. Atmospheric Environment 43, 3645-3647.

Wang, Y., Zhu, Y., Salinas, R., Ramirez, D., Karnae, S., John, K., 2008. Roadside measurements of ultrafine particles at a busy urban intersection. Journal of the Air \& Waste Management Association 58, 1449-1457.

Wang, Y.J., Nguyen, M.T., Steffens, J.T., Tong, Z., Wang, Y., Hopke, P.K., Zhang, K.M., 2013. Modeling multi-scale aerosol dynamics and micro-environmental air quality near a large highway intersection using the CTAG model. Science of the Total Environment 443, 375-386.

Wang, Y.J., Zhang, K.M., 2009. Modeling Near-Road Air Quality Using a Computational Fluid Dynamics Model, CFD-VIT-RIT. Environmental Science \& Technology 43, 7778-7783.

Weber, S., 2009. Spatio-temporal covariation of urban particle number concentration and ambient noise. Atmospheric Environment 43, 5518-5525.

Wiedensohler, A., $\quad$ Birmili, W., $\quad$ Nowak, A., Sonntag, A., Weinhold, K., Merkel, M., Wehner, B., Tuch, T., Pfeifer, S., Fiebig, M., Fjäraa, A. M., Asmi, E., Sellegri, K., Depuy, R., Venzac, H., Villani, P., Laj, P., Aalto, P., Ogren, J. A., Swietlicki, E., Williams, P., Roldin, P., Quincey, P., Hüglin, C., Fierz-Schmidhauser, R., Gysel, M., Weingartner, E., Riccobono, F., Santos, S., Grüning, C., Faloon, K., Beddows, D., Harrison, R., Monahan, C., Jennings, S. G., O'Dowd, C. D., Marinoni, A., Horn, H.G., Keck, L., Jiang, J., Scheckman, J., McMurry, P. H., Deng, Z., Zhao, C. S., Moerman, M., Henzing, B., de Leeuw, G., Löschau, G., and Bastian, S.: Mobility particle size spectrometers: harmonization of technical standards and data structure to facilitate high quality long-term observations of atmospheric particle number size distributions, Atmospheric Measurement Techniques, 5, 657-685, doi:10.5194/amt-5657-2012, 2012.

Wehner, B., Birmili, W., Gnauk, T., Wiedensohler, A., 2002. Particle number size distributions in a street canyon and their transformation into the urban-air background: measurements and a simple model study. Atmospheric Environment 36, 2215-2223.

Wehner, B., Uhrner, U., von Löwis, S., Zallinger, M., Wiedensohler, A., 2009. Aerosol number size distributions within the exhaust plume of a diesel and a gasoline passenger car under on-road conditions and determination of emission factors. Atmospheric Environment 43, 1235-1245.

Westerdahl, D., Wang, X., Pan, X., Zhang, K.M., 2009. Characterization of on-road vehicle emission factors and microenvironmental air quality in Beijing, China. Atmospheric Environment 43, 697-705.

Wu, X.M., Fan, Z.T., Ohman-Strickland, P., 2010. Time-location patterns of a population living in an air pollution hotspot. Journal of Environmental and Public Health 2010. vol. 2010, Article ID 625461,10 pages. doi:10.1155/2010/625461

Goel, A., Kumar, P., 2014. A review of fundamental drivers governing the emissions, dispersion and exposure to vehicle-emitted nanoparticles at signalised traffic intersections. Atmospheric Environment 97, 316-331. Online link: http://www.sciencedirect.com/science/article/pii/S1352231014006311 
WHO, 2014. Ambient (outdoor) air pollution database by country and city, United Nations (New York). http://www.who.int/phe/health_topics/outdoorair/databases/cities/en/ (accessed 04 August 2014).

Zhang, K.M., Wexler, A.S., Zhu, Y.F., Hinds, W.C., Sioutas, C., 2004. Evolution of particle number distribution near roadways. Part II: the 'Road-to-Ambient'process. Atmospheric Environment 38, 6655-6665.

Zhang, L., Ma, J., 2012. A study on multi-resolution modeling of mesoscopic-microscopic traffic simulation model. American Sociey of Civil Engineers, pp. 695-706. doi: 10.1061/9780784412442.071.

Zhang, Y., 2008. Online-coupled meteorology and chemistry models: history, current status, and outlook. Atmospheric Chemistry and Physics 8, 2895-2932.

Zheng, Z., Durbin, T.D., Xue, J., Johnson, K.C., Li, Y., Hu, S., Huai, T., Ayala, A., Kittelson, D.B., Jung, H.S., 2013a. Comparison of particle mass and solid particle number (SPN) emissions from a heavy-duty diesel vehicle under on-road driving conditions and a standard testing cycle. Environmental Science \& Technology 48, 1779-1786.

Zheng, J., Ma, X., Wu, Y.-J., Wang, Y., 2013b. Measuring Signalized Intersection Performance in Real-Time With Traffic Sensors. Journal of Intelligent Transportation Systems 17, 304-316.

Zhu, X., Fan, Z.T., Wu, X., Meng, Q., Wang, S.-w., Tang, X., Ohman-Strickland, P., Georgopoulos, P., Zhang, J., Bonanno, L., 2008. Spatial variation of volatile organic compounds in a "Hot Spot" for air pollution. Atmospheric Environment 42, 73297338 .

Goel, A., Kumar, P., 2014. A review of fundamental drivers governing the emissions, dispersion and exposure to vehicle-emitted nanoparticles at signalised traffic intersections. Atmospheric Environment 97, 316-331. Online link: http://www.sciencedirect.com/science/article/pii/S1352231014006311 


\section{List of Figure Captions}

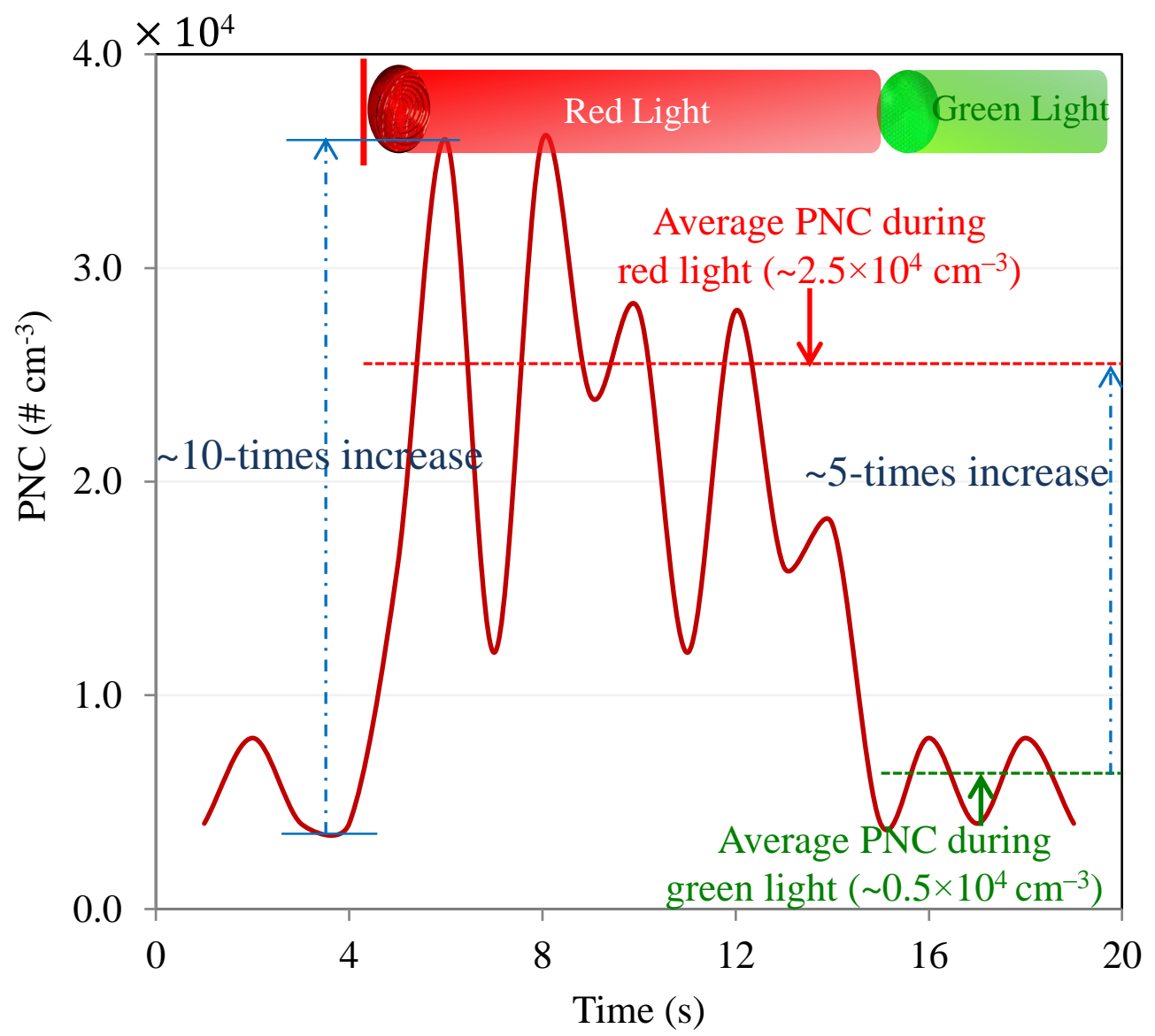

Figure 1. Temporal variation in PNCs as a function of traffic light at a TI (Wang et al., 2008).

\section{Citation details:}

Goel, A., Kumar, P., 2014. A review of fundamental drivers governing the emissions, dispersion and exposure to vehicle-emitted nanoparticles at signalised traffic intersections. Atmospheric Environment 97, 316-331. Online link: http://www.sciencedirect.com/science/article/pii/S1352231014006311 


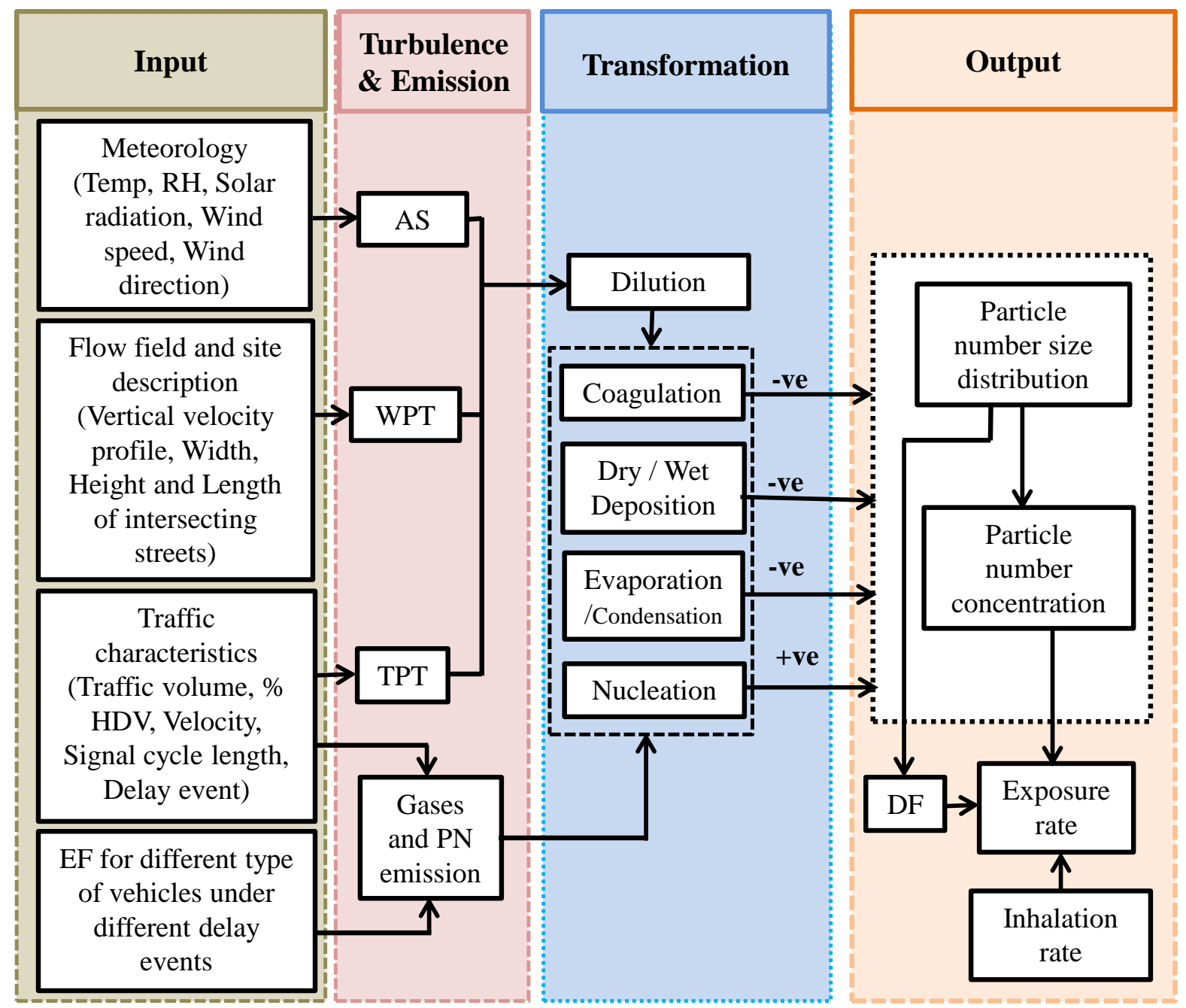

Figure 2. A simplified modelling framework for estimating PNC and associated exposure at the TIs. AS, DF, PN, EF, HDV, TPT and WPT refer to atmospheric stability, deposited fraction, particle number, emission factors, heavy-duty vehicles, traffic-produced turbulence and wind-produced turbulence, respectively.

Citation details:

Goel, A., Kumar, P., 2014. A review of fundamental drivers governing the emissions, dispersion and exposure to vehicle-emitted nanoparticles at signalised traffic intersections. Atmospheric Environment 97 , 316-331. Online link: http://www.sciencedirect.com/science/article/pii/S1352231014006311 

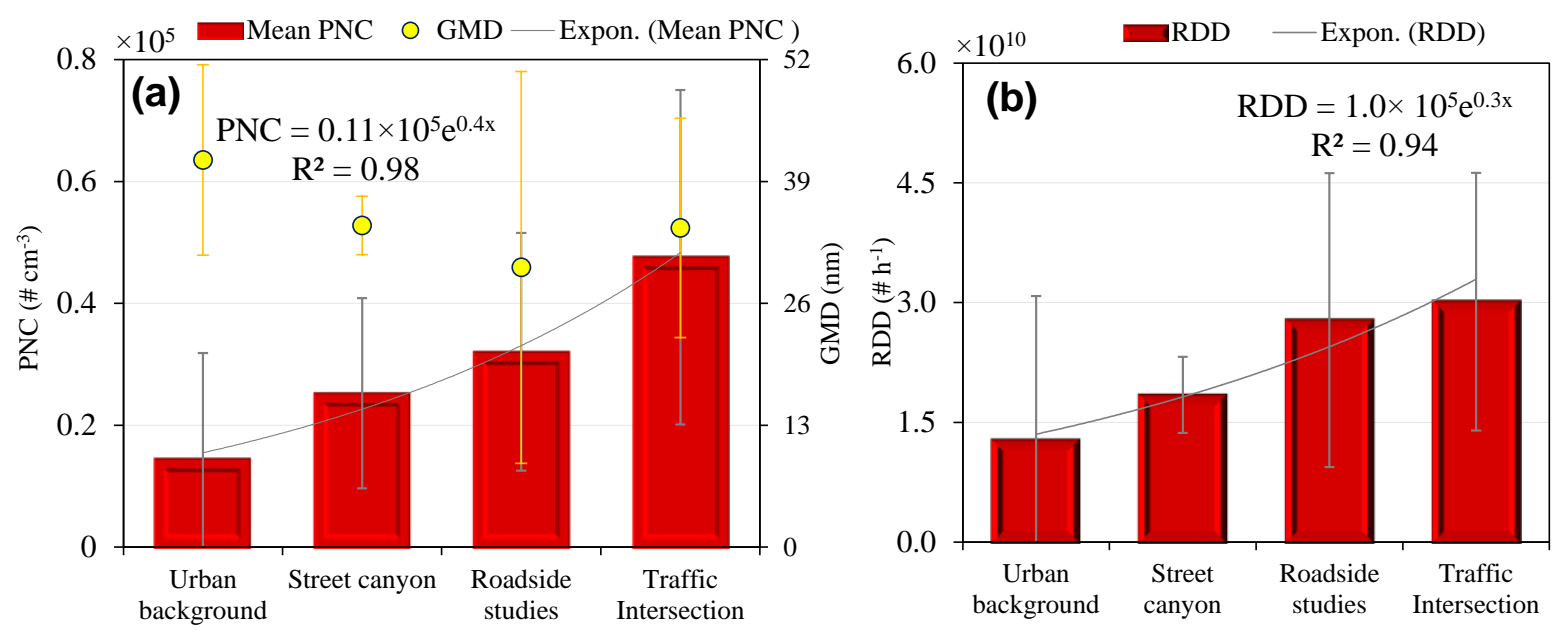

Figure 3. (a) Summary of average PNCs and the corresponding geometrical mean diameters (GMD) observed in different environments; these values are taken as average of various studies summarised in SI Table S1. (b) Summary of average RDDs estimated for different environments, based on the average PNC values presented in SI Table S1. In studies where GMD was not given, average GMD of that environment is considered to quantify appropriate RDD. Also are shown the correlation among the PNC values (and RDD) in different environments. For the correlation equations shown in both the figures, $x$ is equal to 1, 2, 3 and 4 for urban background, street canyon, roadside and traffic intersection, respectively.

\section{Citation details:}

Goel, A., Kumar, P., 2014. A review of fundamental drivers governing the emissions, dispersion and exposure to vehicle-emitted nanoparticles at signalised traffic intersections. Atmospheric Environment 97, 316-331. Online link: http://www.sciencedirect.com/science/article/pii/S1352231014006311 


\section{List of Tables}

Table 1. Summary of relevant field studies covering measurements of PNCs at the TIs.

\begin{tabular}{|c|c|c|c|c|c|c|c|}
\hline $\begin{array}{l}\text { Author } \\
\text { (year) }\end{array}$ & $\begin{array}{l}\text { City } \\
\text { (Country) }\end{array}$ & $\begin{array}{l}\text { Instrume } \\
\text { nts }\end{array}$ & $\begin{array}{l}\text { Size } \\
\text { range } \\
(\mathrm{nm})\end{array}$ & $\begin{array}{l}\text { Maxim } \\
\text { um } \\
\text { PNC } \\
\left(\times 10^{5}\right. \\
\left.\mathrm{cm}^{-3}\right)\end{array}$ & $\begin{array}{l}\text { Traffic } \\
\text { density } \\
\left(h^{-1}\right)\end{array}$ & $\begin{array}{l}\text { HDV Months } \\
(\%)\end{array}$ & Remarks \\
\hline $\begin{array}{l}\text { Moraws } \\
\text { ka et al. } \\
(2004)\end{array}$ & $\begin{array}{l}\text { Salzburg } \\
\text { (Austria) }\end{array}$ & SMPS & $\begin{array}{l}13- \\
830\end{array}$ & $0.2^{\mathrm{a}}$ & 3600 & $\begin{array}{ll}20- & \text { Septemb } \\
30 \% & \text { er }\end{array}$ & $\begin{array}{l}\text { Sampling point was around } 5 \\
\mathrm{~m} \text { away from the road and } \\
1.2 \mathrm{~m} \text { above the ground. }\end{array}$ \\
\hline $\begin{array}{l}\text { Holmes } \\
\text { et al. } \\
(2005)\end{array}$ & $\begin{array}{l}\text { Brisbane } \\
\text { (Australia) }\end{array}$ & SMPS & 9-407 & 2.6 & $\begin{array}{l}200- \\
1920\end{array}$ & $20 \%^{\mathrm{a}}$ January & $\begin{array}{l}\text { Monitoring is carried out at } \\
\text { one fixed site that is } \\
\text { surrounded by river on south } \\
\text { side and buildings on other } \\
\text { three corners. }\end{array}$ \\
\hline $\begin{array}{l}\text { Tsang et } \\
\text { al. } \\
(2008)\end{array}$ & $\begin{array}{l}\text { Mong Kok } \\
\text { of Kowloon } \\
\text { (Hong } \\
\text { Kong) }\end{array}$ & WCPC & $\begin{array}{l}5- \\
2000\end{array}$ & 5.4 & 840 & $29 \%$ July & $\begin{array}{l}\text { Monitoring was carried out } \\
\text { at three fixed sites. } \\
\text { Intersection was street } \\
\text { canyon intersection bounded } \\
\text { on all sides by high rise } \\
\text { buildings. These sites were } \\
\text { located at } 1 \mathrm{~m}, 5 \mathrm{~m} \text { and } 6 \mathrm{~m} \\
\text { distance from intersecting } \\
\text { roads, respectively. }\end{array}$ \\
\hline $\begin{array}{l}\text { Wang et } \\
\text { al. } \\
(2008)\end{array}$ & $\begin{array}{l}\text { Texas } \\
\text { (USA) }\end{array}$ & $\begin{array}{l}\text { CPC \& } \\
\text { SMPS } \\
\text { with } \\
\text { DMA }\end{array}$ & $7-290$ & 2.4 & $\begin{array}{l}10452- \\
11897\end{array}$ & $\begin{array}{c}\text { 3.7\% Decemb } \\
\text { er-June }\end{array}$ & $\begin{array}{l}\text { Mobile sampling was carried } \\
\text { out at four corners of an } \\
\text { intersection along with } \\
\text { sampling at one fixed site on } \\
\text { the south-east corner of the } \\
\text { intersection. Measurements } \\
\text { were conducted both in } \\
\text { upwind and downwind } \\
\text { direction of both roadways. }\end{array}$ \\
\hline $\begin{array}{l}\text { Oliveira } \\
\text { et al. } \\
\text { (2009) }\end{array}$ & $\begin{array}{l}\text { Optro } \\
\text { (Portugal) }\end{array}$ & $\mathrm{CPC}$ & $6-700$ & 1.07 & 2500 & $25 \%^{\mathrm{a}}$ July & $\begin{array}{l}\text { Sampling site was located in } \\
\text { the city centre at } 3 \mathrm{~m} \\
\text { distance from intersecting } \\
\text { roads. }\end{array}$ \\
\hline $\begin{array}{l}\text { Fujitani } \\
\text { et al. } \\
\text { (2012) }\end{array}$ & $\begin{array}{l}\text { Kawasaki } \\
\text { City } \\
\text { (Japan) } \\
\end{array}$ & SMPS & $8-300$ & $\sim 1.4$ & 2167 & $25 \%$ January & $\begin{array}{l}\text { Monitoring was carried out } \\
\text { at intersection of industrial } \\
\text { road and main highway. }\end{array}$ \\
\hline $\begin{array}{l}\text { Holder } \\
\text { et al. } \\
(2014)\end{array}$ & $\begin{array}{l}\text { North } \\
\text { Carolina } \\
\text { (USA) }\end{array}$ & EEPS & $6-560$ & $0.7^{\mathrm{b}}$ & - & April & $\begin{array}{l}\text { Mobile measurements were } \\
\text { carried out on a specified } \\
\text { route to assess the spatial } \\
\text { variability. }\end{array}$ \\
\hline
\end{tabular}

Note: ${ }^{a}$ Average PNC $;{ }^{b} 90^{\text {th }}$ percentile $;$ Proportion of diesel-fuelled vehicles out of total vehicle fleet; EPS = Engine Exhaust Particle Sizer; SMPS = Scanning Mobility Particle Sizer; CPC = Condensation Particle Counter; WCPC $=$ Water-based CPC

Citation details:

Goel, A., Kumar, P., 2014. A review of fundamental drivers governing the emissions, dispersion and exposure to vehicle-emitted nanoparticles at signalised traffic intersections. Atmospheric Environment 97, 316-331. Online link: http://www.sciencedirect.com/science/article/pii/S1352231014006311 
Table 2. Summary of review article discussing flow field and dispersion modelling of inert pollutants at TIs, besides studies focusing on nanoparticle dispersion modelling and regulation implications during the past one decade.

\begin{tabular}{|c|c|}
\hline Author (year) & Study Focus \\
\hline Ahmad et al. (2005) & $\begin{array}{l}\text { Reviewed the effect of building configurations, canyon geometries, } \\
\text { traffic induced turbulence and variable approaching wind directions on } \\
\text { flow fields and exhaust dispersion in urban street canyons and } \\
\text { intersections, based on wind tunnel simulations studies. }\end{array}$ \\
\hline Biswas and $\mathrm{Wu}(2005)$ & $\begin{array}{l}\text { Reviewed the state of knowledge on formation and potential use of } \\
\text { manufactured and anthropogenic airborne nanoparticles. }\end{array}$ \\
\hline $\begin{array}{l}\text { Holmes and Morawska } \\
\text { (2006) }\end{array}$ & $\begin{array}{l}\text { Reviewed the dispersion modelling techniques that can be applied } \\
\text { within different environments, in regards to scale, complexity of the } \\
\text { environment and concentration parameters. }\end{array}$ \\
\hline $\begin{array}{l}\text { Nowack and Bucheli } \\
\text { (2007) }\end{array}$ & $\begin{array}{l}\text { Classified different types of nanoparticles and summarised their } \\
\text { formation, emission, occurrence and fate in the environment. }\end{array}$ \\
\hline $\begin{array}{l}\text { Buseck and Adachi } \\
(2008)\end{array}$ & $\begin{array}{l}\text { Discussed physical and chemical properties of airborne nanoparticles } \\
\text { and their significance from health and climate change perspective. }\end{array}$ \\
\hline $\begin{array}{l}\text { Ju-Nam and Lead } \\
(2008)\end{array}$ & $\begin{array}{l}\text { Discussed physicochemical aspects of manufactured and natural } \\
\text { aquatic nanoparticles to assess their toxicity and fate in the natural } \\
\text { aquatic environment. }\end{array}$ \\
\hline $\begin{array}{l}\text { Morawska et al. } \\
(2008)\end{array}$ & $\begin{array}{l}\text { Reviewed information on vehicle generated ultrafine particles related } \\
\text { to their characteristics and dynamics in the air in the context of the } \\
\text { human exposure and epidemiological studies as well as in relation to } \\
\text { their management and control in vehicle affected environments. }\end{array}$ \\
\hline $\begin{array}{l}\text { Morawska et al. } \\
\text { (2009) }\end{array}$ & $\begin{array}{l}\text { Reviewed the existing instrumental methods to monitor airborne } \\
\text { nanoparticles in different types of indoor and outdoor environments. }\end{array}$ \\
\hline $\begin{array}{l}\text { Simonet and Valcárcel } \\
(2009)\end{array}$ & $\begin{array}{l}\text { Described some methodological aspects relating to the fields of } \\
\text { nanoparticle analysis, nanometrology and analytical chemistry. }\end{array}$ \\
\hline Kumar et al. (2010a) & $\begin{array}{l}\text { Reviewed potential prospects of regulatory control for atmospheric } \\
\text { nanoparticles, recent advances on this topic and future research } \\
\text { priorities. }\end{array}$ \\
\hline Kumar et al. (2010b) & $\begin{array}{l}\text { Compared the behaviour of manufactured and vehicle derived airborne } \\
\text { nanoparticles and discussed the consequences for prioritising research } \\
\text { and regulation activities. }\end{array}$ \\
\hline Kumar et al. (2010c) & $\begin{array}{l}\text { Discussed the potential impact of the particle number concentrations } \\
\text { derived from biofuel vehicles on existing regulatory concerns over } \\
\text { atmospheric nanoparticles. }\end{array}$ \\
\hline Morawska (2010) & $\begin{array}{l}\text { Summarised the state of knowledge on possible health impacts of } \\
\text { airborne engineered nanoparticles generated in commercial and } \\
\text { research facilities. }\end{array}$ \\
\hline $\begin{array}{l}\text { Carpentieri et al. } \\
(2011)\end{array}$ & $\begin{array}{l}\text { Reviewed the research work relevant to modelling the dispersion of } \\
\text { nanoparticles in vehicle wake. }\end{array}$ \\
\hline Knibbs et al. (2011) & $\begin{array}{l}\text { Reviewed the state of knowledge on determinant, variability and } \\
\text { transport mode-dependence of exposure to ultrafine particles during } \\
\text { commuting. }\end{array}$ \\
\hline Kumar et al. (2011b) & Synthesised information related to current practices of nanoparticle \\
\hline
\end{tabular}




\begin{tabular}{ll}
\hline & $\begin{array}{l}\text { dispersion modelling at five different local scales (i.e. vehicle wake, } \\
\text { street canyons, neighbourhood, city and road tunnels). }\end{array}$ \\
\hline Kumar et al. (2011a) & $\begin{array}{l}\text { Discussed the technical challenges that are needed to be tackled before } \\
\text { developing a regulatory framework for atmospheric nanoparticles. }\end{array}$ \\
\hline Morawska et al. & $\begin{array}{l}\text { Reviewed the existing regulations, policy measures and health } \\
\text { guidelines related to reduction of airborne particulate matter (both on } \\
\text { mass and number based) concentration. }\end{array}$ \\
\hline Tiwary et al. (2011) & $\begin{array}{l}\text { Reviewed the current practice in monitoring, modelling flow fields and } \\
\text { inert pollutant concentrations at urban road intersections and the } \\
\text { implications for commuter exposure. }\end{array}$ \\
\hline Kumar et al. (2012) & $\begin{array}{l}\text { Discussed the importance of nanoparticles generated by building and } \\
\text { construction activities and their associated exposure. }\end{array}$ \\
\hline Kumar et al. (2013b) & $\begin{array}{l}\text { Synthesised the existing information on 11 non-vehicle exhaust } \\
\text { sources of urban nanoparticles. }\end{array}$ \\
\hline Kumar et al. (2014) & $\begin{array}{l}\text { Reviewed the studies related to road traffic-emitted particle number } \\
\text { emissions and concentrations in European and Asian cities and } \\
\text { presented an integrated evaluation of emissions and population } \\
\text { exposure. }\end{array}$ \\
\hline
\end{tabular}

Citation details

Goel, A., Kumar, P., 2014. A review of fundamental drivers governing the emissions, dispersion and exposure to vehicle-emitted nanoparticles at signalised traffic intersections. Atmospheric Environment 97 , 316-331. Online link: http://www.sciencedirect.com/science/article/pii/S1352231014006311 
Table 3. Review of some of the key wind tunnel and numerical simulation references (studies) explaining features of wind flow at the TIs.

\begin{tabular}{|c|c|}
\hline Studies & Study focus \\
\hline \multicolumn{2}{|c|}{ Wind tunnel simulations } \\
\hline $\begin{array}{l}\text { Hoydysh and } \\
\text { Dabberdt (1994); } \\
\text { Dabberdt et al. } \\
(1995)\end{array}$ & $\begin{array}{l}\text { Studied the dispersion of tracer gas at TI of orthogonal streets by means } \\
\text { of wind tunnel experiments. They found that maximum tracer gas } \\
\text { concentration values were consistently located at street corners, and the } \\
\text { street aspect ratio had an important influence on dispersion conditions at } \\
\text { the TIs. }\end{array}$ \\
\hline $\begin{array}{l}\text { Kastner-Klein et al. } \\
\text { (1997) }\end{array}$ & $\begin{array}{l}\text { Studied the tracer gas concentration field at simple perpendicular TIs of } \\
\text { symmetrical street canyons for reference wind direction of } 90^{\circ} \text { by } \\
\text { means of wind tunnel experiments. }\end{array}$ \\
\hline Robins et al. (2002) & $\begin{array}{l}\text { Studied the dispersion of tracer gas at a simple TI of two perpendicular } \\
\text { streets through wind tunnel experiments. They found that the exchange } \\
\text { of wind flow between the main street and side street were negligible in } \\
\text { symmetrical situation. Small departures in symmetry were sufficient to } \\
\text { establish significant exchanges. }\end{array}$ \\
\hline Klein et al. (2007) & $\begin{array}{l}\text { Studied the effect of building height on wind flow and pollutant } \\
\text { dispersion pattern at urban TI through wind tunnel experiments. }\end{array}$ \\
\hline $\begin{array}{l}\text { Carpentieri et al. } \\
\text { (2009) }\end{array}$ & $\begin{array}{l}\text { Studied the mean flow, turbulence and flow path lines at a street canyon } \\
\text { TI by using flow visualisation and Laser Doppler Anemometry methods } \\
\text { in wind tunnel experiments. }\end{array}$ \\
\hline $\begin{array}{l}\text { Brixey et al. (2009); } \\
\text { Heist et al. (2009) }\end{array}$ & $\begin{array}{l}\text { Carried out wind tunnel measurements and CFD simulations of wind } \\
\text { flow features in an idealized urban array of three story row houses. They } \\
\text { also studied the effect of tall tower located at downwind edge of one of } \\
\text { these houses on wind flow features. }\end{array}$ \\
\hline Soulhac et al. (2009) & $\begin{array}{l}\text { Studied wind flow and dispersion mechanism at urban TIs of orthogonal } \\
\text { streets. By using the results of wind tunnel and numerical modelling, } \\
\text { they developed a new operational model for pollutant exchanges at the } \\
\text { TIs. }\end{array}$ \\
\hline $\begin{array}{l}\text { Carpentieri et al. } \\
(2012)\end{array}$ & $\begin{array}{l}\text { Studied mean and turbulent tracer flux balance in geometries of real } \\
\text { street canyon TI (DAPPLE site) through wind tunnel experiments. }\end{array}$ \\
\hline Kukačka et al. (2012) & $\begin{array}{l}\text { Studied the vertical advection and turbulent scalar fluxes at X-shaped TI } \\
\text { for five different reference wind directions by means of wind tunnel } \\
\text { experiments. }\end{array}$ \\
\hline Ahmad (2013) & $\begin{array}{l}\text { Studied the combined effect of traffic induced turbulence and natural } \\
\text { wind flow on tracer gas dispersion at urban TI through wind tunnel } \\
\text { experiments. }\end{array}$ \\
\hline \multicolumn{2}{|l|}{ CFD simulations } \\
\hline Gadilhe et al. (1993) & $\begin{array}{l}\text { Carried out numerical simulation of wind flow for a complex and } \\
\text { realistic TI using a standard k- } \epsilon \text { model of turbulence. They found fairly } \\
\text { good agreement between wind tunnel measurements and model results. }\end{array}$ \\
\hline $\begin{array}{l}\text { Scaperdas and } \\
\text { Colvile (1999) }\end{array}$ & $\begin{array}{l}\text { Carried out CFD simulations to understand the effect of wind direction } \\
\text { on small scale dispersion patterns at TIs. }\end{array}$ \\
\hline
\end{tabular}

Citation details:

Goel, A., Kumar, P., 2014. A review of fundamental drivers governing the emissions, dispersion and exposure to vehicle-emitted nanoparticles at signalised traffic intersections. Atmospheric Environment 97 , 316-331. Online link: http://www.sciencedirect.com/science/article/pii/S1352231014006311 
Table 4. Comparison of flow field features at a TI of symmetrical street canyons of aspect ratio of 1 (Case 1) and TI of symmetrical and asymmetrical street canyons (Case 2) (Scaperdas and Colvile, 1999; Soulhac et al., 2009).

\begin{tabular}{llll}
$\begin{array}{l}\text { Wind } \\
\text { direction } \\
\text { with } \\
\text { respect to } \\
\text { street } \\
\text { reference }\end{array}$ & $\begin{array}{l}\text { Case 1 } \\
\text { btreet canyons in } \\
\text { both the directions } \\
\text { and they all have } \\
\text { aspect ratio }=1)\end{array}$ & $\begin{array}{l}\text { Case } 2 \\
\text { (Street canyons in } \\
\text {-direction are } \\
\text { asymmetrical and } \\
\text { street canyons in } \\
x \text {-direction are } \\
\text { symmetrical) }\end{array}$ & $\begin{array}{l}\text { In both cases, flow seperation at the } \\
\text { upstream corner of the side streets } \\
\text { leads to the formation of recirculating } \\
\text { vortices at the enterance of two side } \\
\text { streets. }\end{array}$ \\
\hline$\varnothing=0^{0}$
\end{tabular}

Citation details:

Goel, A., Kumar, P., 2014. A review of fundamental drivers governing the emissions, dispersion and exposure to vehicle-emitted nanoparticles at signalised traffic intersections. Atmospheric Environment 97 , 316-331. Online link: http://www.sciencedirect.com/science/article/pii/S1352231014006311 
Table 5. Description and limitations of various PNEFs derivation techniques.

\begin{tabular}{|c|c|c|c|c|}
\hline Method & Description & $\begin{array}{l}\text { Influencing } \\
\text { factors }\end{array}$ & Limitations & Source \\
\hline $\begin{array}{l}\text { Laboratory testing } \\
\text { (engine and chassis } \\
\text { dynamometer } \\
\text { studies) }\end{array}$ & $\begin{array}{l}\text { Emission measurements are } \\
\text { carried out under controlled } \\
\text { conditions in laboratories. } \\
\text { PNEFs derived by this } \\
\text { method represent the } \\
\text { strength of source, but do } \\
\text { not take into account the } \\
\text { effect of transformation } \\
\text { processes on PNEFs. }\end{array}$ & $\begin{array}{l}\text { Vehicle type, } \\
\text { driving } \\
\text { condition, } \\
\text { engine load }\end{array}$ & $\begin{array}{l}\text { PNEFs derived by this } \\
\text { method may not } \\
\text { represent PN emissions } \\
\text { under real-world } \\
\text { conditions with sufficient } \\
\text { accuracy. }\end{array}$ & $\begin{array}{l}\text { Jayaratne et al. } \\
\text { (2009); Morawska et } \\
\text { al. (1998); Ristovski } \\
\text { et al. (2005); } \\
\text { Ristovski et al. } \\
\text { (2004) }\end{array}$ \\
\hline $\begin{array}{l}\text { Measurement under } \\
\text { real-world } \\
\text { conditions (road } \\
\text { tunnel, remote } \\
\text { sensing, on-road } \\
\text { chasing technique } \\
\text { and on-board } \\
\text { emissions } \\
\text { measurements) }\end{array}$ & $\begin{array}{l}\text { Emission measurements are } \\
\text { carried out under real-world } \\
\text { conditions to yield the data } \\
\text { regarding the actual } \\
\text { emission behaviour of road } \\
\text { vehicles in real world } \\
\text { conditions. Since } \\
\text { measurements are carried } \\
\text { out near the receptor, } \\
\text { PNEFs derived by this } \\
\text { method takes in to account } \\
\text { the effect of transformation } \\
\text { processes but does not } \\
\text { represent the actual strength } \\
\text { of the source. }\end{array}$ & $\begin{array}{l}\text { Vehicle type, } \\
\text { driving } \\
\text { condition, } \\
\text { engine load, } \\
\text { road grade and } \\
\text { metrology }\end{array}$ & $\begin{array}{l}\text { In case of road tunnel } \\
\text { studies, it is challenging } \\
\text { to apportion emissions to } \\
\text { specific vehicle classes } \\
\text { unless different tunnel } \\
\text { bores are dedicated to } \\
\text { them. In case of remote } \\
\text { sensing technique, } \\
\text { instantaneous emission } \\
\text { rates associated with } \\
\text { driving conditions at a } \\
\text { particular point on the } \\
\text { road are measured. } \\
\text { Therefore these may not } \\
\text { be a representative of } \\
\text { average emissions over a } \\
\text { full drive cycle. On-road } \\
\text { chase techniques are best } \\
\text { conducted on a test track } \\
\text { due to traffic safety } \\
\text { considerations. On-board } \\
\text { measurements such as } \\
\text { portable emission } \\
\text { measurements systems } \\
\text { add additional mass } \\
\text { ( 30-70 kg) to the } \\
\text { vehicle that may bias the } \\
\text { measurements, especially } \\
\text { for light-weight cars. }\end{array}$ & $\begin{array}{l}\text { Samaras et al. } \\
(2005) ; \text { Holmen et } \\
\text { al. (2005); Janhäll et } \\
\text { al. (2004); } \\
\text { Rosenbohm et al. } \\
\text { (2005); Morawska et } \\
\text { al. (2005); Nickel et } \\
\text { al. (2013); Keogh } \\
\text { and Sonntag (2011); } \\
\text { Wehner et al. } \\
\text { (2009); Hak et al. } \\
\text { (2009); Franco et al. } \\
\text { (2013) }\end{array}$ \\
\hline $\begin{array}{l}\text { Inverse modelling } \\
\text { technique }\end{array}$ & $\begin{array}{l}\text { PNEF are derived on basis } \\
\text { of road side measurements } \\
\text { after accounting for } \\
\text { dispersion of particles using } \\
\text { an inverse modelling } \\
\text { approach. }\end{array}$ & & $\begin{array}{l}\text { Since the method uses a } \\
\text { nanoparticle dispersion } \\
\text { model to estimate the } \\
\text { PNEFs, the accuracy of } \\
\text { the estimated PNEFs } \\
\text { depends on the ability of } \\
\text { the model to reproduce } \\
\text { the dispersion of PN } \\
\text { emissions. }\end{array}$ & $\begin{array}{l}\text { Kumar et al. } \\
\text { (2008a); Kumar et } \\
\text { al. (2008b); } \\
\text { Morawska et al. } \\
\text { (2005); Zhang et al. } \\
\text { (2004) }\end{array}$ \\
\hline
\end{tabular}

Citation details:

Goel, A., Kumar, P., 2014. A review of fundamental drivers governing the emissions, dispersion and exposure to vehicle-emitted nanoparticles at signalised traffic intersections. Atmospheric Environment 97, 316-331. Online link: http://www.sciencedirect.com/science/article/pii/S1352231014006311 
Table 6. Comparison of different types of microscopic emission models.

\begin{tabular}{|c|c|c|c|c|c|c|c|}
\hline Source & Model & Type & $\begin{array}{l}\text { Road } \\
\text { grade }\end{array}$ & $\begin{array}{l}\text { Vehicle } \\
\text { categorie } \\
\text { S }\end{array}$ & $\begin{array}{l}\text { Pollutant } \\
\text { types }\end{array}$ & $\begin{array}{l}\text { Cold start } \\
\text { emission }\end{array}$ & Remark \\
\hline $\begin{array}{l}\text { Rakha et } \\
\text { al. } \\
(2003)\end{array}$ & $\begin{array}{l}\text { Comprehens } \\
\text { ive modal } \\
\text { emission } \\
\text { model } \\
\text { (CMEM) }\end{array}$ & $\mathrm{L}$ & $\mathrm{N}$ & $\begin{array}{l}\text { LDV } \\
\text { and } \\
\text { HDV }\end{array}$ & $\begin{array}{l}\mathrm{CO}_{2}, \mathrm{CO}, \\
\mathrm{HC} \text { and } \\
\mathrm{NOx}\end{array}$ & $\mathrm{Y}$ & $\begin{array}{l}\text { Model exhibit } \\
\text { abnormal } \\
\text { behaviour at low } \\
\text { speed and high } \\
\text { acceleration. }\end{array}$ \\
\hline $\begin{array}{l}\text { Boulter } \\
\text { et al. } \\
(2007)\end{array}$ & $\begin{array}{l}\text { Digitized } \\
\text { Graz Model } \\
(\mathrm{DGV})\end{array}$ & EM & $\mathrm{N}$ & Cars & $\begin{array}{l}\mathrm{CO}_{2}, \mathrm{CO}, \\
\mathrm{HC}, \mathrm{PM} \text { and } \\
\mathrm{NOx}\end{array}$ & $\mathrm{Y}$ & -- \\
\hline $\begin{array}{l}\text { Boulter } \\
\text { et al. } \\
(2007)\end{array}$ & MODEM & EM & $\mathrm{N}$ & Cars & $\begin{array}{l}\mathrm{CO}_{2}, \mathrm{CO}, \\
\mathrm{HC}, \mathrm{PM} \text { and } \\
\mathrm{NOx}\end{array}$ & $\mathrm{N}$ & $\begin{array}{l}\text { Model estimation } \\
\text { for particulate } \\
\text { matter emissions } \\
\text { is not good. } \\
\text { Therefore there is } \\
\text { a need to look at } \\
\text { PM emission } \\
\text { estimates } \\
\text { cautiously. }\end{array}$ \\
\hline $\begin{array}{l}\text { Boulter } \\
\text { et al. } \\
(2007)\end{array}$ & $\begin{array}{l}\text { Passenger } \\
\text { car and } \\
\text { Heavy-duty } \\
\text { Emission } \\
\text { Model } \\
\text { (PHEM) }\end{array}$ & EM & $\mathrm{N}$ & $\begin{array}{l}\text { Cars and } \\
\text { HDVs }\end{array}$ & $\begin{array}{l}\mathrm{CO}_{2}, \mathrm{CO}, \\
\mathrm{HC}, \mathrm{PM} \text { and } \\
\mathrm{NOx}\end{array}$ & $\mathrm{N}$ & $\begin{array}{l}\text { HDV part of the } \\
\text { model does not } \\
\text { include the } \\
\text { distortion in } \\
\text { emissions due to } \\
\text { traffic signals. } \\
\text { Emission maps } \\
\text { are solely based } \\
\text { on the regulatory } \\
\text { testing and hence } \\
\text { significantly } \\
\text { underestimate the } \\
\text { emission levels. }\end{array}$ \\
\hline $\begin{array}{l}\text { Boulter } \\
\text { et al. } \\
(2007)\end{array}$ & $\begin{array}{l}\text { Vehicle } \\
\text { Transient } \\
\text { Emissions } \\
\text { Simulation } \\
\text { Software } \\
\text { (VeTESS) } \\
\end{array}$ & EM & $\mathrm{Y}$ & $\begin{array}{l}\text { Cars and } \\
\text { HDVs }\end{array}$ & $\begin{array}{l}\mathrm{CO}_{2}, \mathrm{CO}, \\
\mathrm{HC}, \mathrm{PM} \text { and } \\
\mathrm{NOx}\end{array}$ & $\mathrm{N}$ & $\begin{array}{l}\text { Model also } \\
\text { contains emission } \\
\text { maps for } \\
\text { transient } \\
\text { conditions. }\end{array}$ \\
\hline $\begin{array}{l}\text { Rakha et } \\
\text { al. } \\
(2003)\end{array}$ & $\begin{array}{l}\text { Virgina } \\
\text { Tech } \\
\text { Microscopic } \\
\text { energy and } \\
\text { emission } \\
\text { model (VT- } \\
\text { Micro) }\end{array}$ & $\mathrm{S}$ & $Y$ & $\begin{array}{l}\text { LDVs } \\
\text { and } \\
\text { trucks }\end{array}$ & $\begin{array}{l}\mathrm{CO}, \mathrm{HC} \text { and } \\
\mathrm{NOx}\end{array}$ & $\mathrm{N}$ & $\begin{array}{l}\text { Emission } \\
\text { estimates by } \\
\text { model are found } \\
\text { consistent with } \\
\text { the laboratory } \\
\text { measurements. }\end{array}$ \\
\hline
\end{tabular}

Note: $\mathrm{Y}=$ Yes; $\mathrm{N}=\mathrm{No} ; \mathrm{L}=$ Load based model; $\mathrm{S}=$ Statistical model; EM = Emission map based model

Citation details:

Goel, A., Kumar, P., 2014. A review of fundamental drivers governing the emissions, dispersion and exposure to vehicle-emitted nanoparticles at signalised traffic intersections. Atmospheric Environment 97 , 316-331. Online link: http://www.sciencedirect.com/science/article/pii/S1352231014006311 
Table 7. Timescale analysis of various transformation processes at TIs along with their effect on PN and particle volume concentration. Where symbol,,+- 0 represent gain, loss and no effect on number and volume concentrations, respectively.

\begin{tabular}{llcl}
\hline \multirow{2}{*}{$\begin{array}{l}\text { Transformation } \\
\text { Processes }\end{array}$} & \multicolumn{2}{l}{ Effect on concentration } & Timescale (s) $^{\mathrm{a}}$ \\
\cline { 2 - 3 } & Number & Volume & 80 \\
\hline Nucleation & + & + & $10^{2}$ \\
\hline Dilution & \pm & \pm & $10^{3}$ \\
\hline Dry deposition & - & - & - \\
\hline Wet deposition & - & - & $5 \times 10^{3}$ \\
\hline Coagulation & - & 0 & $0.4-8 \times 10^{4}$ \\
\hline Condensation & 0 & + & - \\
\hline Evaporation & $0 /-$ & - & \\
\hline
\end{tabular}

${ }^{a}$ Detailed calculations of time scale analysis are explained in SI Section S2. 
Table 8. Characteristics of a few currently available aerosol dynamic models.

\begin{tabular}{|c|c|c|c|c|c|c|}
\hline Model & Type & $\begin{array}{l}\text { Nucleatio } \\
\mathrm{n}\end{array}$ & $\begin{array}{l}\text { Coagu } \\
\text { lation }\end{array}$ & $\begin{array}{l}\text { Condensati } \\
\text { on/Evapora } \\
\text { tion }\end{array}$ & $\begin{array}{l}\text { Deposit } \\
\text { ion }\end{array}$ & Source \\
\hline MAT & $\begin{array}{l}\text { Combination of a } \\
\text { plume model with a } \\
\text { 1-D Langrangian } \\
\text { trajectory framework }\end{array}$ & $\mathrm{N}$ & $\mathrm{Y}$ & $\mathrm{Y}$ & $\mathrm{Y}$ & $\begin{array}{l}\text { Ketzel and } \\
\text { Berkowic } \\
\mathrm{z}(2005)\end{array}$ \\
\hline GATOR-GCMM & $\begin{array}{l}\text { Unified fully } \\
\text { coupled online } \\
\text { model that account } \\
\text { for major feedbacks } \\
\text { among metrology, } \\
\text { chemistry, aerosol, } \\
\text { cloud and radiation }\end{array}$ & $\mathrm{Y}$ & $\mathrm{Y}$ & $\mathrm{Y}$ & $\mathrm{Y}$ & $\begin{array}{l}\text { Zhang } \\
\text { (2008) }\end{array}$ \\
\hline ADCHEM & Langragian & $\mathrm{Y}$ & $\mathrm{Y}$ & $\mathrm{Y}$ & $\mathrm{Y}$ & $\begin{array}{l}\text { Roldin et } \\
\text { al. (2011) }\end{array}$ \\
\hline CTAG & CFD & $\mathrm{Y}$ & $\mathrm{Y}$ & $\mathrm{Y}$ & $\mathrm{Y}$ & $\begin{array}{l}\text { Wang et } \\
\text { al. (2013) }\end{array}$ \\
\hline
\end{tabular}

Note: $\mathrm{Y}=$ Yes; $\mathrm{N}=\mathrm{No} ;$ MAT $=$ Multi-plume Aerosol dynamic and Transport; GATOR-GCMM = Gas, Aerosol, Transport, Radiation, General Circulation and Mesoscale Meteorological; ADCHEM $=$ Aerosol Dynamic, gas and particle phase CHEMistry; CTAG = Comprehensive Turbulent Aerosol Dynamics and Gas Chemistry.

Citation details:

Goel, A., Kumar, P., 2014. A review of fundamental drivers governing the emissions, dispersion and exposure to vehicle-emitted nanoparticles at signalised traffic intersections. Atmospheric Environment 97, 316-331. Online link: http://www.sciencedirect.com/science/article/pii/S1352231014006311 